\title{
Achieving and Sustaining Social Development with Limited Resources: The Experience of Costa Rica
}

\author{
Carmelo Mesa-Lago
}

\section{Introduction}

In 1993, Costa Rica ranked eighth among the 20 nations of Latin America in terms of per capita GDP (World Bank, 1995a), but it ranked first in terms of social indicators (UNDP, 1995). The life expectancy of its population was the highest in the region, and its poverty incidence and unemployment rate were the lowest.

How has Costa Rica been able to attain such a high level of social development in relation to its relatively low ranking in terms of GDP per capita? This study will attempt to explain the discrepancy between Costa Rica's economic development, as conventionally measured, and its superior performance in social development. A crucial underlying question, relevant to all developing countries, is whether it is feasible to significantly improve social conditions with relatively scarce resources and, if so, what are the conditions (including institutions and policies) necessary for achieving such a feat. A related issue is whether countries such as Costa Rica can undergo economic crisis and reform without sacrificing social development.

In order to answer these questions, this chapter will examine the historical background of the country (section 2). It will then assess (section 3) the level of social development achieved in Costa Rica in terms of health care, education, social security, poverty, and inequality. Statistical series dealing with these areas and covering the period 1960-94 (whenever possible), will be presented and analysed. In section 4, the principal factors that may explain the outstanding social performance of Costa Rica will be studied, including institutional arrangements, particularly the role of the state and key government agencies, as well as resource allocation, distribution, and disbursement. Section 5 will measure the social costs of the 1980 s crisis and the impact of the recovery, and the concluding section (6) will discuss the question of how Costa Rica's social development can be made sustainable.

\section{Historical background}

\section{Physical, demographic and ethno-cultural}

Costa Rica is the fourth smallest country in Latin America, it has no significant topographical barriers, and it has a fertile soil, adequate rain pattern, and a mild 
climate. These physical features are favourable for agriculture, which occupies 56 per cent of the land area, and particularly for banana, coffee, and cattle production. They have also facilitated the development of roads and transportation, which have in turn improved access to social services, particularly health care.

The population of Costa Rica is the third smallest of Latin America: 3.4 million in 1995. Population density is relatively high (67 inhabitants per square kilometre), but considerably lower than in other small countries such as Haiti (243) or El Salvador (257). In 1994, 52 per cent of Costa Rica's population was rural, with most of the rural population settled in the Central Valley, a sub-tropical zone blessed with fertile soil and abundant water, high population density, proximity to urban centres, and good communication and transportation facilities. One fourth of the total population lives in the metropolitan area, but there are no large shanty towns.

One of Costa Rica's major problems has been its high population growth rate, which has made it more difficult to achieve high GDP per capita growth rates. In the last 35 years, nevertheless, Costa Rica's per capita growth rate matched and, in 1991-5, doubled the regional average. Because Costa Rica has a relatively young population, its ratio of active insured per pensioner has been high, and this has eased Costa Rica's pension burden. The large young segment of Costa Rica's population, however, has increased the nation's health care, education and other social costs. As the productive age segment of Costa Rica's population expands in the next two decades, the country's dependency ratio will decline and become one of the lowest in the region (the older segment of the population will also expand but at a much lower rate than the productive-age segment).

Finally, Costa Rican society is ethnically and culturally homogenous. Only one language is spoken (Spanish) and there are no isolated ethnic groups. The indigenous population accounts for less than 1 per cent of the total population and is fully integrated culturally and economically. Immigration from poorer neighbouring countries, due to civil wars in the 1970s and 1980s, put pressure on Costa Rica's resources at a difficult time, and imported some diseases that had previously been eradicated. But the pacification and political stabilization in surrounding countries in the 1990 s has led to a migration reversal which has helped to reduce these pressures and problems (Mesa-Lago, 1992, 1994a; IDB, 1994b; ECLAC, 1996).

\section{Historical}

In colonial times, Costa Rica had no rich metals, it had extensive forests that required clearing for agriculture, and it had a small dispersed indigenous population. All of these factors saved the country from the Spanish encomienda, or Indian servitude, and the hacienda system. In the nineteenth century, as there was plenty of land available and little manpower, municipalities granted land parcels to farmers; this land policy also worked against the development of latifundia. Coffee became a major crop (due to favourable climate and soil conditions, as well as world demand) and, since manpower was scarce and coffee requires labour intensive cultivation, wages increased. In addition, coffee plantations required a relatively small investment, and thus facilitated capital accumulation. The con- 
nection with the world economy through coffee exports also promoted imports and the exchange of ideas, while the need to export coffee led to the development of roads and ports. Large-scale banana production was introduced by foreign companies such as United Fruit, and this plantation system led to land concentration and the further growth of wage labour. The expansion of the coffee and banana export sector promoted economic growth but also income inequality. Costa Rican governments originally professed laissez faire ideology, supported free enterprise and trade, and did not intervene in economic and social affairs. Three reforms movements - in 1885-9, 1940-44 and 1948 - changed this policy stance, however, with each one further strengthening state intervention.

In 1885-9 a liberal government introduced important reforms such as the reduction of the military budget and increase in educational expenditures to reduce illiteracy. Primary school was made compulsory for both sexes (sanctions were imposed on parents who did not comply), four secondary schools were established (one for girls), and teachers were paid out of fiscal revenue (IDB, 1994b).

In the 1930s Costa Rica was an agrarian country almost exclusively dependent on coffee and banana exports, with a tiny underdeveloped industrial sector. Most workers were in the rural sector and were not organized, and urban labour was not important. The Great Depression caused a plunge in the world prices of Costa Rica's exports, as well as in government revenue (which came mainly from export taxes), and unemployment rapidly increased. The worsening of economic and social conditions led to labour unrest, confrontations with the banana companies and the founding of the communist party, thus challenging the conservative elite. The 1940 election to the presidency of Rafael Calderón Guardia (a believer in Christian-inspired social reform) led to a break with the conservative elite, the amendment of the Constitution in 1942 to establish 'social guarantees', the enactment of a Labour Code and a Land Law, and the implementation of a series of social reforms which significantly expanded the state's role. These reforms included freedom to organize unions, mandatory collective bargaining, government regulated minimum wages, protection of workers against arbitrary dismissal, labour courts, land distribution, creation of the public National University, and the introduction of social security.

Electoral fraud in the 1948 elections prompted a victorious revolt led by José Figueres, a coffee grower who favoured social policies which would improve living conditions and impede the growth of the radical left. He led a brief interim government (Junta) in 1948-9, was elected president twice, organized the National Liberation Party (PLN), and enacted a new Constitution in 1949. His revolution strengthened the role of the state and influenced Costa Rican politics for decades to follow. Some of the social reforms introduced by successive governments in 1948-80 were the transfer of United Fruit schools, clinics and housing to the state; creation of the Ministry of Labour and Social Security; job creation, largely in the central government, autonomous institutions and public enterprises; wage increases and the addition of many fringe benefits; adult education, the expansion of mandatory public secondary education, the establishment of a national training institute, the strengthening of the national university and the creation of three 
others; the extension of social security coverage and the introduction of primary health care programmes for marginal urban and rural groups; implementation of public housing programmes; efforts to reduce urban-rural inequalities and the development of anti-poverty programmes.

The severe crisis of the 1980 s - the worst since the Great Depression - adversely impacted upon these social programmes, challenged the 35-year strategy of economic and social development, and prompted a structural adjustment reform (Mesa-Lago, 1996b). The crisis of the 1980s, the response to it, and the outcome in terms of social indicators, will be discussed further below.

\section{Political}

Costa Rica is the only nation in Latin America that through most of the twentieth century (and certainly in the second half) has had uninterrupted pluralistic democracy, free elections, peaceful transitions of power between leaders and parties with divergent ideologies, no armed forces, and a high degree of political consensus and stability (the 1948 revolution was very brief and the ensuing Junta, led by Figueres, lasted 18 months and, in 1949, returned power to the 1948 elected president who was a conservative). This political climate has played a crucial positive role in social development.

In the period 1953-96, the PLN has controlled the Executive in seven terms, for a total so far of 27 years. Different opposition parties and coalitions more conservative than the PLN have elected presidents for four terms, totalling 16 years. Furthermore, the PLN has enjoyed a majority in the National Assembly (Legislative Branch) since 1953, except for two terms: 1978-82 when the crisis erupted, and 1990-94. The social policies introduced by President Calderón Guardia in 1940-44 were ratified and steadily expanded since 1953 under PLN dominance; they have had wide popular support, and the opposition parties have been unable to dislodge them. In fact, it was two PLN presidents who introduced the first two structural adjustment programmes and cuts in social expenditures in 1982-90. There has been, therefore, remarkable support and continuity in Costa Rica's public social policies for almost six decades (Mesa-Lago, 1996b).

The first action to reduce the armed forces budget and transfer those resources to social services occurred in the mid-1880s and, by 1890 , the public education budget was bigger than that of the military. The Constitution of 1949 abolished the armed forces, and thus generated a substantial 'peace dividend' that was used largely for social development (IDB, 1994b). In 1992, Costa Rica's defence expenditure equalled 0.9 per cent of GDP or US $\$ 16$ yearly per capita (at 1985 prices), there were no armed forces, and the defence expenditure was 5 per cent of the combined expenditures on education and health care (UNDP, 1995). The latter figure is much lower than most other Latin American countries (see Table 7.1).

\section{The nature and extent of social achievements}

In spite of the adverse effects of the 1980 crisis, in the early 1990s Costa Rica ranked first in the region concerning social indicators. Table 7.1 compares Costa 




कू

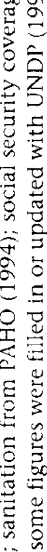

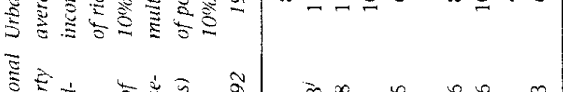

要密

$\stackrel{4}{\square}$

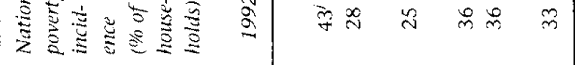

莺

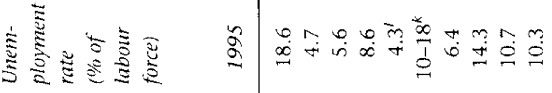

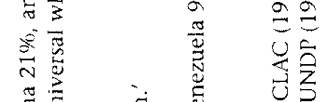

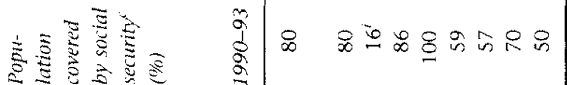

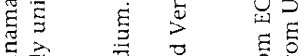

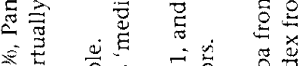

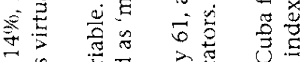

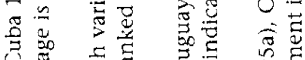

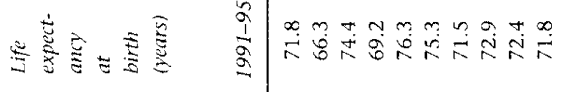

U.

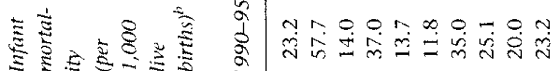

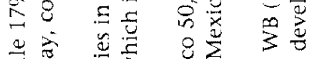

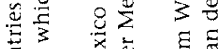

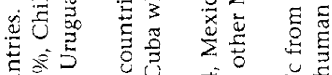

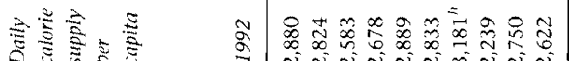

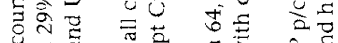

प苍苛

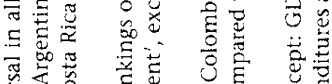

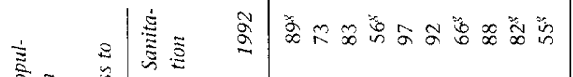

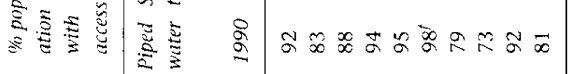

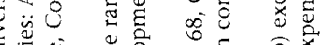

๘

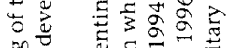

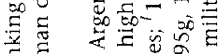

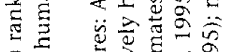

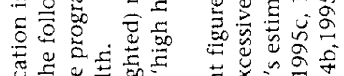

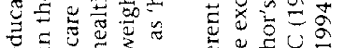

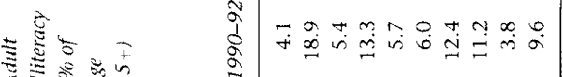

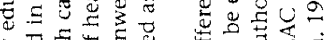

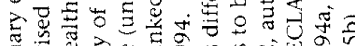

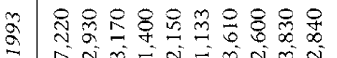

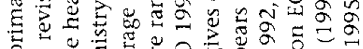

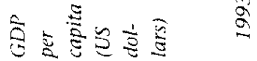



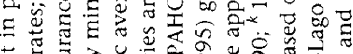

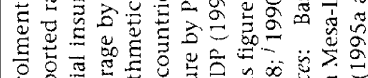

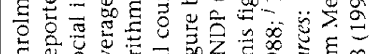


Rica and nine other Latin American countries on 14 indicators. (The remaining 10 countries are well below Costa Rica on economic and social development.) The first column of the table shows that Costa Rica ranked eighth on the first indicator, GDP per capita. Costa Rica ranked in first or second place in ten of the other 13 (social) indicators. It ranked first overall, based on the unweighted average ranking (score) of all countries in each of the 14 indicators.

The last two columns of Table 7.1 reproduce the UNDP (1995) Human Development Index ranking, which is based on three major indicators: life expectancy at birth; education (a combination of adult illiteracy and total educational enrolment); and adjusted real GDP per capita based on purchasing power parity rates in US dollars (PPP\$). The UNDP Index ranks Costa Rica in the 28th place among 174 countries in the world (it is in 58th place in terms of PPP\$), and first among the 20 Latin American countries.

\section{Health Care}

In 1994 , access to health care was virtually universal. In the same year, the percentage of children below one year immunized against contagious diseases was close to 90 per cent (World Bank, 1995a). In 1991, 96 per cent of all births took place in hospitals and 95 per cent were attended by a physician or obstetric nurse (PAHO, 1994).

Costa Rica's exceptional health-care coverage and facilities, combined with very good nutrition and housing, and above-average income per capita have led to health conditions which rank among the best two in Latin America. As Table 7.2 shows, the general or crude mortality rate per 1,000 inhabitants steadily declined from 1960-82. The crude mortality rate stabilized until 1988 and thereafter seems to have slightly increased, mainly as an outcome of declining population growth and the start of the ageing process of the population.

The two most significant indicators of health standards are the infant mortality rate and life expectancy. In 1950 the infant mortality rate was 94 per thousand (IDB, 1994b); Table 7.2 shows a steady decline in this figure: to 82.5 in 1964 and to 13.7 in 1993. Life expectancy at birth was 57 years in 1950 (IDB 1994b) and had risen to 61.6 years in 1960; a steady increase occurred thereafter, with life expectancy reaching 76.3 years in 1993 - a gain of 19 years from 1950 to 1993 .

In 1975, slightly over half of children under 6 years old suffered some degree of malnutrition (most of this was mild malnutrition). By 1992, this figure had declined to 21 per cent, and malnourished children were concentrated in rural areas. Diarrhoeal diseases as a cause of infant death moved from first place in 1970 (27 per cent of all deaths) to the seventh place in 1991 (3 per cent of all deaths). Maternal mortality per 10,000 live births was cut by half from 1975-90, from 7 to 3.5. Daily calories per capita increased from 2,409 in $1969-71$ to 2,711 in 1992 , while daily grams of protein per capita rose from 52.5 to 63.9 (PAHO, 1994; ECLAC, 1996b).

The available data on rates of nine contagious diseases reported per 100,000 inhabitants are presented in Table 7.3. The table shows mixed results: five diseases were eradicated (diphtheria and polio) or virtually eliminated (tetanus, typhoid 


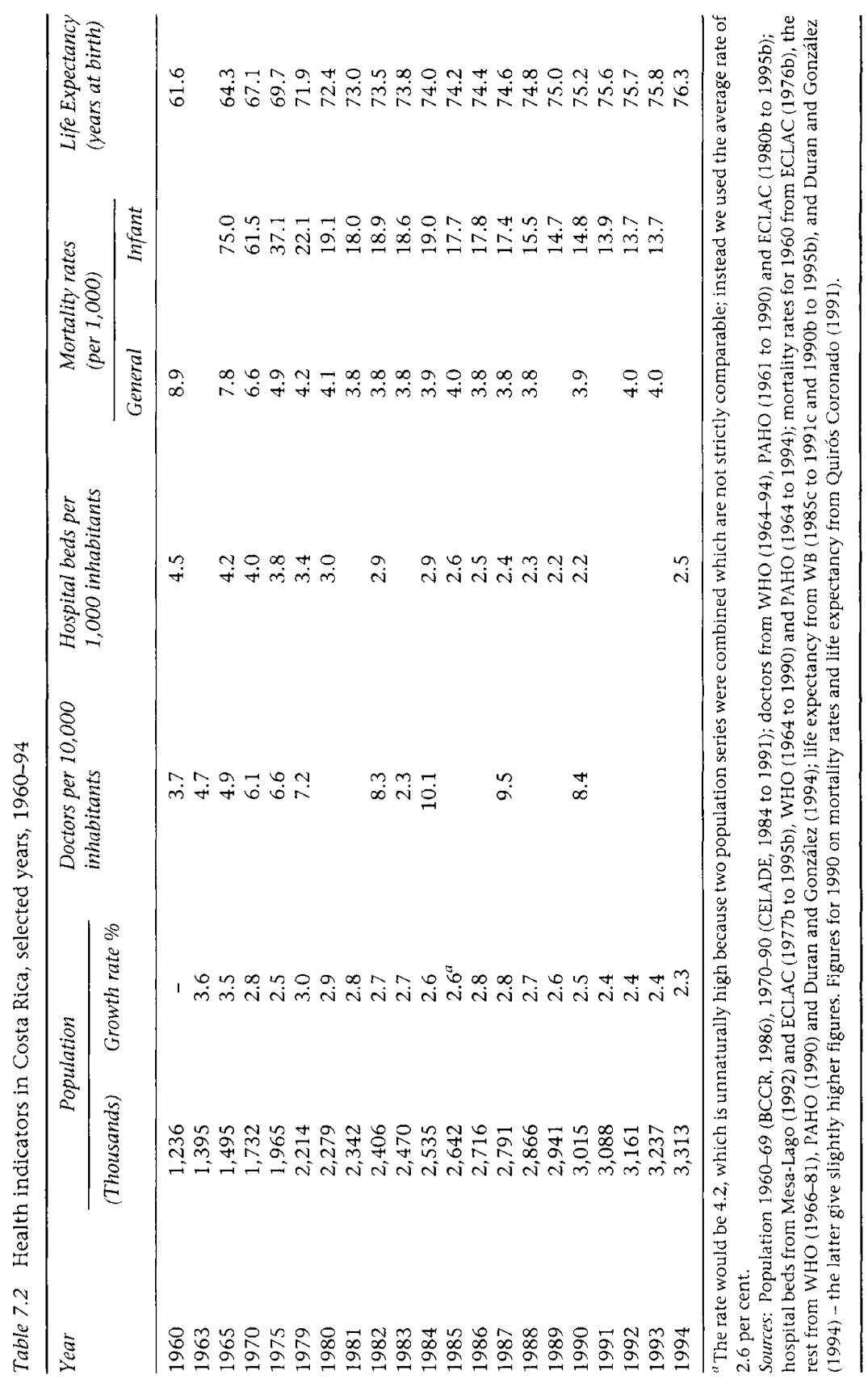




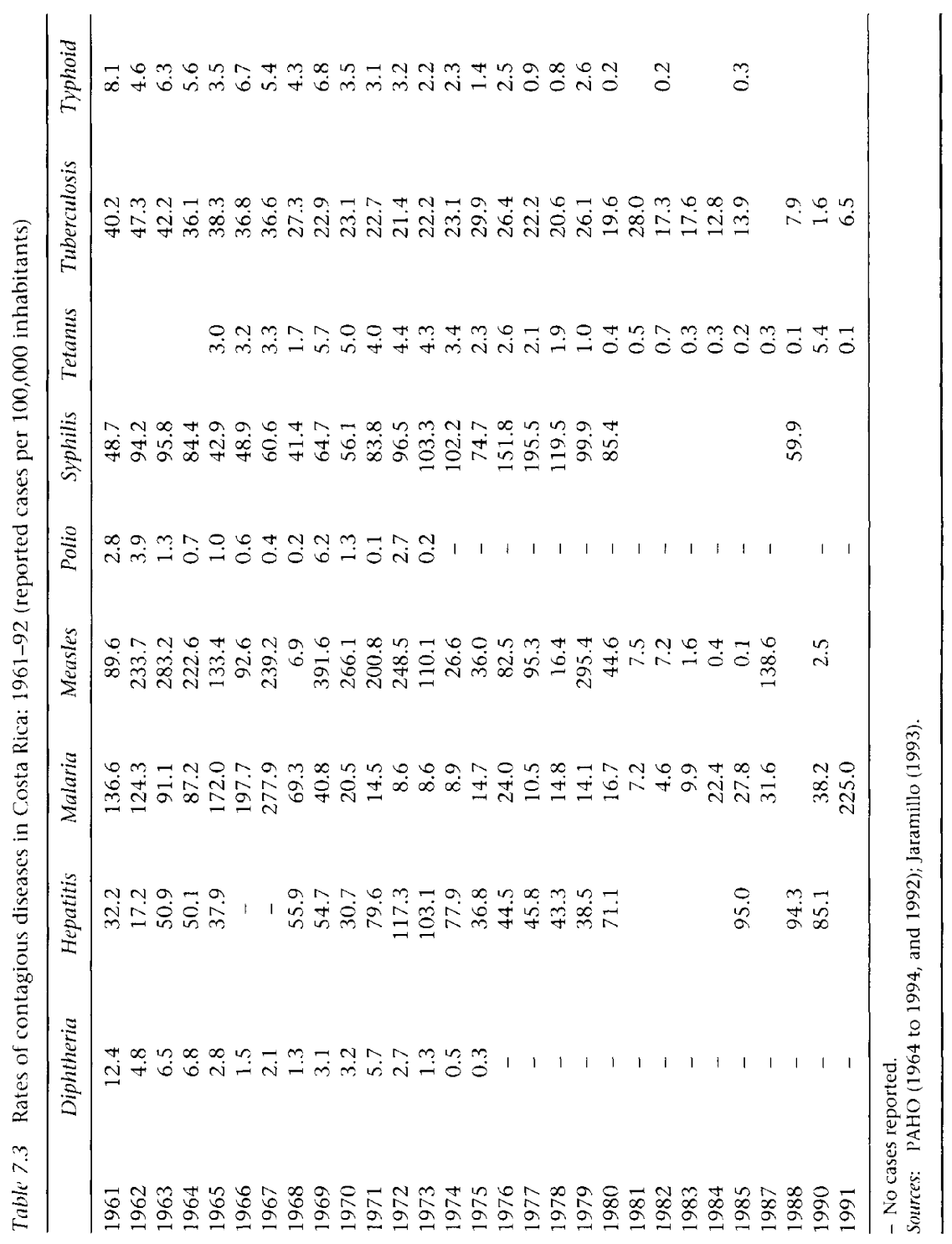


and tuberculosis, although an increase in the latter occurred in 1992). The other four diseases proved more difficult to control. Part of the increase in infectious diseases can be explained by immigration from other Central American countries with lower health standards: in 1993 undocumented aliens made up nearly 8 per cent of the total population. In 1992, 17 per cent of malaria cases occurred among foreigners and 75 per cent were detected in the province of Limon, which is a focus of immigration (PAHO, 1994).

Overall, however, the pathological and morbidity profile of Costa Rica in 1991 was similar to that of developed countries; the four major causes of death were cardiovascular diseases, malignant neoplasms, external causes (traffic accidents, violence), and diseases of the respiratory system. Contagious and parasitic diseases, which in 1970 ranked as the leading cause of death (20.5 per cent), ranked 10 th in 1991 and were responsible for only 2.8 per cent of all deaths (PAHO, 1994).

Table 7.4 shows the access of the population to potable water and sanitary sewage disposal. In urban areas, access to potable water was nearly universal by the end of the 1960s, while sewerage access increased from below 30 per cent to 100 per cent between 1960 and 1983. In rural 'concentrated' areas, about onethird of the population had access to potable water in 1960; this figure rose to 86 per cent in 1989. Sewerage and excreta disposal in 'concentrated' rural areas, which was non-existent in 1960, reached 94 per cent of the population in 1989.

Two key indicators of health facilities are doctors per 10,000 inhabitants and hospital beds per 1,000 inhabitants. The first exhibited an increasing trend from 1960 to 1984 , but a subsequent decline, possibly due to immigration. The hospital bed ratio shows an almost steady declining trend from 1960 to 1990 . A similar

Table 7.4 Access to potable water and sewerage service in Costa Rica: 1960-91

\begin{tabular}{|c|c|c|c|c|}
\hline \multirow[t]{2}{*}{ Year } & \multicolumn{2}{|c|}{$\%$ of urban population } & \multicolumn{2}{|c|}{$\%$ of rural population } \\
\hline & water & sewerage $e^{l}$ & water & sewerage $^{a}$ \\
\hline 1960 & 97.9 & 28.7 & 36.4 & \\
\hline 1964 & 96.6 & 29.7 & 42.8 & \\
\hline 1969 & 100.0 & 21.7 & 53.6 & \\
\hline 1973 & 100.0 & 40.1 & 66.0 & \\
\hline 1977 & 100.0 & 42.2 & 62.7 & 4.0 \\
\hline 1979 & 99.9 & 43.0 & 64.0 & \\
\hline 1980 & 100.0 & 92.0 & 68.0 & 82.0 \\
\hline 1983 & 100.0 & 100.0 & 82.0 & 87.0 \\
\hline 1985 & 100.0 & 99.0 & 83.0 & 89.5 \\
\hline 1988 & 100.0 & 100.0 & 84.0 & 92.9 \\
\hline 1989 & 100.0 & 100.0 & 85.5 & 94.3 \\
\hline 1991 & 100.0 & 100.0 & & \\
\hline
\end{tabular}

"Sanitary sewers, septic tanks and latrines

Sources: ECLAC. (1983b, 1988b); PAHO (1973 to 1990); Jaramillo (1993); UNDP (1995). 
decreasing trend is observed in most Latin American countries; in the case of Costa Rica it may have been caused by complete or virtual elimination of certain diseases (such as tuberculosis and polio), reduction in the population growth rate (less need for paediatric hospitals), better utilization of existing resources, and fewer funds allocated to expand hospital facilities; but it could also been caused by increasing crowding in hospitals.

\section{Education}

Costa Rica's educational system has several distinctions: (a) early creation of compulsory public primary education and introduction of public secondary schools (in the late nineteenth century), and a big push for primary-level universalization in the 1950s and 1960s; (b) a very low illiteracy rate, high enrolment ratios, and equality in access by gender; and (c) relative homogeneity (but still with important rural-urban gaps that were aggravated by the 1980 s crisis) (IDB, 1994b).

The educational system is divided into four major levels: (a) pre-school for children below age 6; (b) primary, for children from 6 to 11 years; (c) secondary (formal or 'academic' and technical-vocational) for students between 12 and 16 years of age; and (d) higher education provided by universities and technological schools. The Constitution establishes that education is mandatory to 9 th grade, and provides support for public higher education.

Table 7.5 summarizes the most important general indicators of education in Costa Rica for the period 1963-93. National illiteracy rates (among 10 years and

Table 7.5 Illiteracy rates and gross enrolment rates in Costa Rica, selected years, 1963-93

\begin{tabular}{lccccccc}
\hline Year & \multicolumn{3}{c}{ Illiteracy rates $^{c}$} & & \multicolumn{3}{c}{ Enrolment in education $^{b}$} \\
\cline { 2 - 3 } \cline { 6 - 7 } & National & Urban & Rural & & Elementary & Secondary & Higher \\
\hline 1963 & 14.3 & 5.2 & 19.7 & 93 & 20 & 5 \\
1970 & & & & 110 & 28 & 9 \\
1973 & 10.2 & 4.4 & 14.7 & 113 & 39 & 13 \\
1977 & & & & 110 & 44 & 19 \\
1980 & & & & 106 & 47 & 23 \\
1984 & 6.9 & \multirow{2}{*}{3.1} & 10.2 & 98 & 41 & 22 \\
1987 & & & & 98 & 41 & 25 \\
1990 & & & & 101 & 42 & 26 \\
1991 & & & & 102 & 43 & 28 \\
1992 & 5.7 & & & 105 & 46 & \\
1993 & & & & 105 & 47 & \\
\hline
\end{tabular}

"Percentages for 1963,1973 and 1984 are from population census, based on 10 years and older. UNESCO gives the following percentages based on 15 years and older: 1973, 11.6, 4.9, 17.6; 1984, 7.4; $1990,7.2$.

${ }^{b}$ Elementary is 6-11 years; secondary is 12-16; and higher is 20-24. The gross enrolment rate is the total enrolment, regardless of age, divided by the population of the age group which correspond to a specific level of education. The net enrolment rate is based on those enrolled who correspond to the age group of the level considered (there are no long series available on net enrolment).

Sources: ECLAC (1980b to 1996b); MEP (1993); UNISCO (1994); IDB (1995a); WB (1995a). 
older, based on population census) were reduced from by more than half from 1963 to 1992, when only 6 per cent of the population was illiterate. The rural illiteracy rate - although very low by regional standards - was almost twice as high. There are no differences in illiteracy rates by gender.

Enrolment ratios at the pre-school level increased from 52 per cent to 66 per cent in 1985-93 (UNESCO 1993, 1994). Table 7.5 shows gross enrolment rates for the next three educational levels from 1963 to 1993. The primary school enrolment rate was above 100 per cent for most of this period (indicating universal coverage and/or a proportion of students not corresponding with the proper grade), with a dip in the crisis years. The enrolment rate at the secondary level steadily grew from 20 per cent in 1963 to a peak of 53 per cent in 1978; it also fell during the crisis years, and stood at 45 per cent in 1993. The higher education enrolment rate increased from 5 per cent in 1963-5 to 28 per cent in 1991. Interestingly, higher education was less affected by the crisis than was secondary education. The reasons for this will be discussed further below.

As in the case of illiteracy, there are no significant gender differences in enrolment rates at the three educational levels. In the regional context, Costa Rica's almost equal access to education by gender is a remarkable accomplishment in a society that was predominantly rural until 1996.

The average student-teacher ratio at the primary level was about 29 in 1970-80 but it increased to 32 in 1988 . The corresponding ratio at the secondary level was 23 in 1970-75. This decreased to 17 in 1985, but rose in 1988-92, reaching 20 in the latter years (UNESCO 1993, 1994). The worsening of the student-teacher ratio in the late 1980s and beginning of the 1990s (while the recovery was taking place) cannot be explained by the crisis, as was largely the case with the other two indicators.

The indicators on illiteracy and enrolment suggest that Costa Rica had made impressive progress in education until a regression occurred during the $1980 \mathrm{~s}$ crisis, and that in the 1990s the nation appeared to be on the way to recovering the previous standards. Table 7.6 shows educational achievement for urban and rural populations by age. The clear improvement for the younger age cohorts is the result of the big push for the universalization of education, particularly at the primary level, that took place in the 1950s and 1960s. Table 7.6 also shows, however, significant disparities in educational achievement between the urban and rural populations.

A thorough study conducted by IDB (1994b) on this subject showed urban-rural disparities in attendance, drop out rates and 'regularity' (i.e., matching of age with school grade, vis-à-vis 'irregularity' which denotes enrolment in a grade below the corresponding age). This study also found a positive correlation between low levels of education of parents and high drop out rates and irregularity among their children. An additional problem, found at the secondary level, was the insufficient provision of technical-vocational education, which is geared mostly to rural areas. Instead, there has been an expansion of formal or 'academic' education, which is mostly geared to urban groups, and which comprises 78 per cent of total 


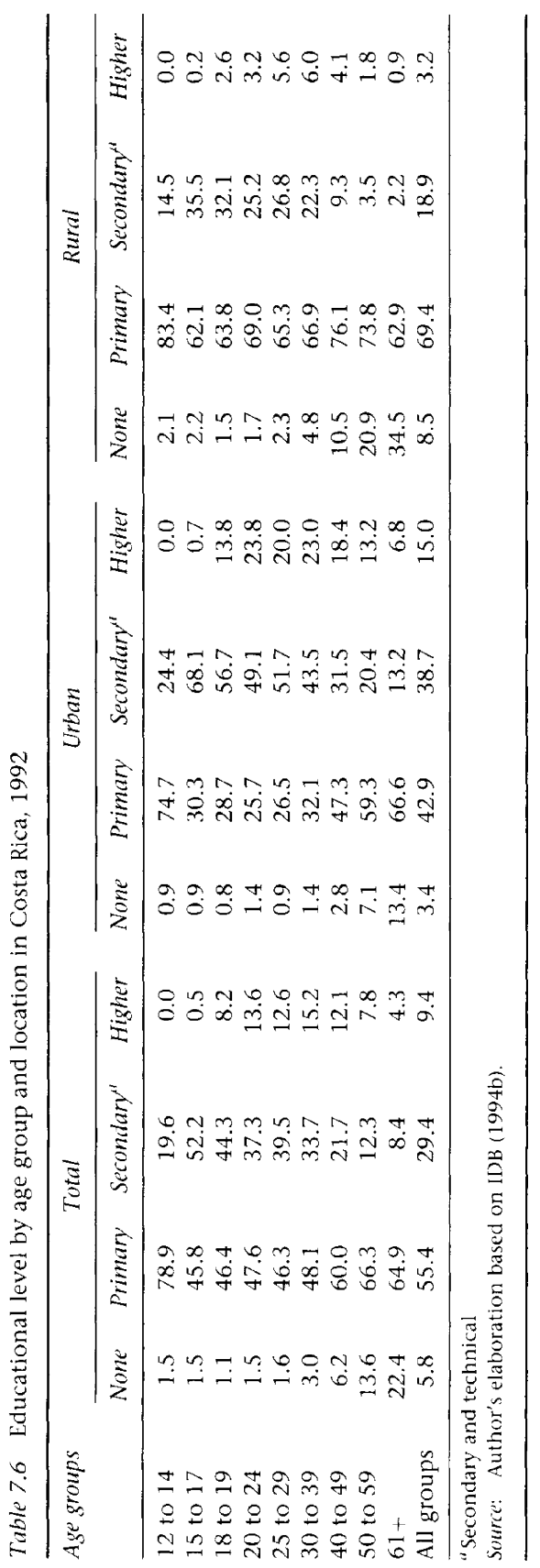


enrolment in secondary education. The IDB study gave the following reasons for this phenomenon: formal secondary education is the entry to an university career which conveys both high social status and the probability of a job in the public sector, while rural vocational schools convey low social status and poor probabilities for employment, hence they have been afflicted by high drop out rates (only one-third of students finish) and stagnation in enrolment.

Higher education is made up of three public universities, one public technological institute, and eight private universities. The Constitution assigns an annual percentage of the fiscal budget to the universities, which ensures their revenue. When resources were abundant (in the 1950s, 1960s and early 1970s) it was possible to expand all three levels of education, but the crisis and scarcity of funds in the 1980 s forced a reduction in overall resources. Because of the constitutional mandate, higher education was protected at the cost of the lower levels (IDB, 1994b).

\section{Social security}

Costa Rica's social security is virtually unique in Latin America because it combines four key features: (a) almost complete coverage of the entire population, at least on health care; (b) incorporation of social insurance (contributory) and social welfare (non-contributory) programmes; (c) integration between most health-care services covered by social insurance and the ministry of public health; and (d) almost complete unification in a single institution and standardization of entitlement conditions.

The general social insurance agency (Caja Costarricense de Seguro Social: CCSS) was established in 1941 and began to function in 1943. Legally, all salaried workers (including domestic servants and employees of microenterprises) are mandatorily covered by the CCSS, while the self-employed, unpaid family workers and employers can join voluntarily. The social security programme is financed primarily through payroll taxes; therefore as the formal sector, salaried labour force, public employment, skilled labour and employment in larger enterprises increases, it is easier to expand coverage. Conversely, the higher the urban informal sector, rural traditional sector, self-employment, unpaid family workers, unskilled labourers, open unemployment and employment in microenterprises, the harder it is to extend coverage. The expansion of social services, particularly social security and health care, has been facilitated in Costa Rica by positive features of its labour force. In 1990-95, the proportion of Costa Rica's EAP that was self-employed, unpaid family workers, unskilled independent workers or in the urban informal sector was the lowest in the region, and 67.5 per cent of the country's workers were salaried employees (based on ECLAC, 1995g).

This is not to say that the composition of the labour force has been the only factor explaining universalization of social security coverage in Costa Rica. Special government policies and subsidies, including low social security taxes and state financial support to the self-employed and other groups difficult to cover, and non-contributory programmes for the non-insured dispossessed, have played a 
crucial role in that outcome. Thus leadership and political commitment have been essential for attaining the goal of maximum coverage.

The CCSS currently administers two programmes: sickness-maternity (SM) and pensions for old-age, disability and survivors (OADS); these are 'contributory' programmes (financed by wage contributions paid by the insured, employers and the government, as a third party), but the CCSS also administers noncontributory programmes for the dispossessed (both SM and OADS) through additional wage contributions, earmarked taxes and state subsidies. Until very recently, there were 20 independent pension funds (OADS) covering various groups of civil servants. All these groups are also covered by the CCSS-SM programme.

The SM programme provides two types of benefits: health-care services, which are essentially curative, and monetary payments (paid leaves for sickness and maternity), while the OADS programme provides monetary benefits only (pensions, lump sums for funeral expenses, and financial aid for prosthesis). Occupational accidents and diseases are covered through a separate agency (Instituto Nacional de Seguros: INS), a state monopoly of all types of insurance created in 1924. It pays pensions for disability and survivors and makes temporary payments for disability and funeral aid, but the INS largely relies on the CCSS for health-care services. Another institution (Fondo de Desarrollo Social y Asignaciones Familiares: FODESAF), established in 1974, transfers funds to the CCSS to finance welfare pensions (and health care to both pensioners and their dependants) for the elderly, the disabled, widowers and abandoned children who are not entitled to contributory benefits and are dispossessed. Finally, the Instituto Mixto de Ayuda Social (IMAS) manages other welfare programmes such as nutrition and subsidies. In the 1970s all hospitals from the Ministry of Health (MINSA) and other institutions were transferred to the CCSS, which in turn, became responsible for offering free care to the dispossessed, with the aid of state transfers. ' MINSA still is in charge of preventive and environmental services, and manages a network of small units that provides primary health care to rural and urban marginal groups (Mesa-Lago, 1989, 1992, 1994a, 1994b).

Statistical series on the coverage of CCSS's two programmes in 1960-94 are presented in Table 7.7. In 1960 only 15 per cent of the total population and 25 per cent of the economically active population (EAP) were covered, with beneficiaries heavily concentrated in San Jose and the provincial capitals. Coverage slowly increased until 1965, when the insured's family dependants became entitled to health care, but the big push to expand protection occurred in the 1970 s due to the following actions: (a) elimination of a salary cap that excluded medium and high income salaried workers from coverage (1970); (b) inclusion of the dispossessed (1974); and (c) extension of coverage to self-employed and pensioners (1975-6). In 1979, before the economic crisis began, 84 per cent of the total population and 75 per cent of the EAP were covered.

The CCSS-SM programme has significantly higher coverage than does the OADS. Coverage was 60 per cent in 1975 and 86 per cent in 1994. Those not covered by the programme are likely to be in rural areas (especially those without 
Table 7.7 Social security coverage and real benefits in Costa Rica, 1960-94

\begin{tabular}{|c|c|c|c|c|c|}
\hline \multirow[t]{3}{*}{ Year } & \multicolumn{3}{|c|}{ Population covered by CCSS (\%) } & \multicolumn{2}{|c|}{$\begin{array}{l}\text { Indices of real benefits per } \\
\text { capita }(1980=100)^{\circ}\end{array}$} \\
\hline & \multicolumn{2}{|c|}{ Health care (SM) } & \multirow{2}{*}{$\begin{array}{l}\text { Pensions } \\
\text { (OADS) EAP }\end{array}$} & \multirow[t]{2}{*}{ All benefits } & \multirow[t]{2}{*}{ Pensions } \\
\hline & Total ${ }^{\prime \prime}$ & $E A P^{x}$ & & & \\
\hline 1960 & 15.0 & 25.0 & 5.9 & & \\
\hline 1965 & 30.0 & 31.0 & 16.8 & 50 & \\
\hline 1970 & 47.2 & 38.3 & 23.6 & 100 & \\
\hline 1975 & 59.6 & 50.1 & 45.4 & 191 & 76 \\
\hline 1976 & 61.2 & 51.2 & & & 87 \\
\hline 1977 & 74.0 & 63.3 & & & 96 \\
\hline 1978 & 82.2 & 71.7 & & & 94 \\
\hline 1979 & 84.3 & 74.9 & & - & 101 \\
\hline 1980 & 75.7 & 67.8 & 50.8 & 100 & 100 \\
\hline 1981 & 71.7 & 65.6 & & 104 & 84 \\
\hline 1982 & 68.0 & 63.5 & & 73 & 54 \\
\hline 1983 & 69.3 & 64.7 & & 71 & 85 \\
\hline 1984 & 83.9 & 67.9 & & 85 & 89 \\
\hline 1985 & 81.4 & 65.3 & & 91 & 116 \\
\hline 1986 & 81.1 & 65.4 & & 96 & 99 \\
\hline 1987 & 82.2 & 66.1 & & 83 & 111 \\
\hline 1988 & 83.0 & 66.6 & 44.8 & 89 & 94 \\
\hline 1989 & 85.4 & 67.5 & 45.8 & 100 & 93 \\
\hline 1990 & 85.6 & 67.0 & 46.2 & & 88 \\
\hline 1991 & 85.9 & 66.4 & 45.9 & & 91 \\
\hline 1992 & 86.2 & 69.0 & 47.5 & & 91 \\
\hline 1993 & 86.2 & 71.0 & 48.9 & & 95 \\
\hline 1994 & 86.2 & 77.3 & 49.3 & & \\
\hline
\end{tabular}

"The figures refer to contributors; actual coverage of health care was virtually universal in 1994 (if the Ministry of Health combined with private coverage were added).

"Excludes coverage by independent funds of civil servants ( 8 per cent of the EAP in 1990) as well as noncontributory pensions.

"For all benefits there are two series, the first base is the year 1970 and the second is 1980 . All benefit index is calculated by ILO; pension index by the author.

Sources: CCSS (1976 to 1991a, 1990b to 1995b, 1995c); Mesa-lago (1989, 1990, 1992, 1994b); IDB (1994b); ILO (1996).

any education), the lowest income quartile, and some occupations such as vendors (typically in the informal sector) and agriculture. But most of these apparently unprotected groups are covered by two primary health care programmes administered by MINSA: one geared to the most remote, dispersed and poor rural population (introduced in 1973), and the other for urban marginal population in shantytowns (established in 1976). In 1987 (after the worst of the crisis was over) MINSA provided these services to 57 per cent of the rural population and 48 per cent of the urban population - overlapping, therefore, with the 86 per cent of the population covered by the CCSS (Mesa-Lago, 1992). This does not mean, however, that there is 100 per cent protection with equal quality of health care 
services for people covered by CCSS-SM and the vulnerable groups covered by MINSA. Although CCSS-SM benefits are fairly strictly controlled, they do include some very generous (and costly) benefits such as medical hospital treatment abroad when not available at home. In 1980, MINSA had a per capita revenue (per person covered) higher than that of CCSS, but the crisis badly affected the former as its resources were cut by one half in 1980-83, precisely when they were most needed by the vulnerable groups it cared for.

The OADS programme expanded significantly from 1960 to 1980, but even at its peak this programme only reached 50 per cent of the population. This was due to several reasons: (a) it does not cover civil servants in independent funds, which account for 8 per cent of the EAP; (b) coverage of the self-employed is not mandatory (less than 4 per cent are covered, compared with 64 per cent of salaried workers) and their contribution to the OADS programme is higher than to the SM programme, so they are more likely to join the latter; and (c) the self-employed and low-income wage earners often claim to be dispossessed in order to qualify for non-contributory welfare pensions (coverage by these pensions is not included in Table 7.7). The crisis of the 1980 s provoked a decline in coverage of both the SM (by 16 percentage points) as well as in OADS (we lack data for 1981-7 but a rough estimate suggests a decline of 13 points), because of increasing unemployment, informal sector employment and evasion. Levels of coverage began to recover in the late 1980s.

Entitlement conditions in the CCSS-OADS programme are quite generous. In 1943, the age of retirement was set at 65 for both sexes, but early retirement was allowed in the late 1960 s and, since 1971, retirement ages were gradually reduced to 55 for women and 57 for men, among the lowest two in Latin America. In the meantime, life expectancy increased dramatically (becoming the highest in the region) hence, the average time period of a pension became the longest, particularly among women who could retire two years younger than men and live an average of six more years. Such generosity was even more remarkable in some of the independent pension funds for civil servants, which allowed retirement at age 50 with 30 years of work. Furthermore the salary base for the CCSS pension was calculated on the best four years in the last five years of work (or on the last year or even the last month in some civil servant funds), and the replacement rate ranged from 55 per cent to 90 per cent in the CCSS, and up to 100 per cent in some civilservant funds. These liberal entitlement conditions provoked significant financial difficulties, and high rates of inflation in 1980-92 aggravated the situation.

\section{Poverty}

National poverty incidence among households in Costa Rica is the second lowest in Latin America, and exhibited a declining trend from 24 per cent in 1970-71 to 13 per cent in 1977 (see Table 7.8). ${ }^{2}$ That trend probably reversed in the first year of the crisis (22 per cent in 1981) and kept growing until it peaked in 1983 at 30 per cent. Those three years of crisis were characterized by the highest unemployment and inflation rates in modern Costa Rican history, sharp declines in both the average real wage and minimum wage, and drastic cuts in public social services. 
Table 7.8 Estimates of poverty incidence among households in Costa Rica, $1970-93$ (percentages of total households)

\begin{tabular}{|c|c|c|c|c|c|c|}
\hline \multirow[b]{2}{*}{ Authors/Years } & \multicolumn{2}{|c|}{ National } & \multicolumn{2}{|c|}{ Urban } & \multicolumn{2}{|c|}{ Rural } \\
\hline & Poverty & Indigency & Poverty & Indigency & Poverty & Indigency \\
\hline \multicolumn{7}{|l|}{ PREALC } \\
\hline 1971 & 39 & 17 & 28 & & 46 & \\
\hline 1977 & 25 & 14 & 14 & & 34 & \\
\hline 1983 & 34 & 16 & 25 & & 44 & \\
\hline 1986 & 25 & 14 & 16 & & 32 & \\
\hline \multicolumn{7}{|l|}{ ECLAC } \\
\hline 1970 & 24 & 6 & 15 & 5 & 30 & 7 \\
\hline 1981 & 22 & 6 & 16 & 5 & 28 & 8 \\
\hline 1988 & 25 & 8 & 21 & 6 & 28 & 10 \\
\hline 1990 & 24 & 10 & 22 & 7 & 25 & 12 \\
\hline 1992 & 25 & 10 & 25 & 8 & 25 & 12 \\
\hline \multicolumn{7}{|l|}{ Sauma/Trejos } \\
\hline 1971 & 25 & 9 & 14 & & 33 & \\
\hline 1977 & 13 & 7 & 8 & & 17 & \\
\hline 1983 & 30 & 14 & 23 & & 37 & \\
\hline 1986 & 17 & 10 & 11 & & 22 & \\
\hline \multicolumn{7}{|l|}{ Trejos } \\
\hline 1988 & 22 & & 11 & & 30 & \\
\hline 1990 & 20 & & 10 & & 29 & \\
\hline 1992 & 22 & & 13 & & 30 & \\
\hline 1993 & 17 & 9 & 9 & 4 & 26 & 14 \\
\hline
\end{tabular}

Summary, national poverty incidence

\begin{tabular}{lcccc}
\hline Years & PREALC & ECLAC & Sauma/Trejos & Trejos/IDB \\
\hline 1970 & 39 & 24 & & \\
1971 & 25 & & 25 & \\
1977 & & 22 & 13 & \\
1981 & 34 & & 30 & \\
1983 & 25 & & 17 & 18 \\
1986 & & 25 & & 22 \\
1987 & & 24 & & 20 \\
1988 & & & & 24 \\
1990 & & 25 & & 17 \\
1991 & & & & 17 \\
1992 & & & & \\
1993 & & & & \\
\hline
\end{tabular}

Sources: Sauma and Trejos (1990); PREALC (1992); ECLAC (1992d,1993,1995g); Trejos (1994); IDB (1994b).

The debt crisis was a major cause of this severe recession, compounded with the adjustment programme of 1982-3, which although successful in curtailing inflation and the fiscal deficit, worsened social conditions and poverty. The first 
structural adjustment programme began in 1985 and the second in 1988, both with aid from the World Bank; they were successful in generating a modest recovery in the second half of the 1980s, a reduction in unemployment, and some increases in real wages, while controlling inflation. Anti-poverty programmes in 1986-95 also helped to reduce poverty. In 1986-90 and 1991-5 poverty incidence declined back to the pre-crisis level.

The rate of indigency in Costa Rica is also one of the lowest two in the region, although some sources estimate an increasing trend. In 1970, indigency incidence was about one fourth of poverty incidence, but in 1993 it was about half and was concentrated in rural areas.

An Inter-American Development Bank study determined the characteristics of the poor in 1993 (IDB, 1995b). Poverty incidence increased as one moved away from the metropolitan area. One-fifth of female-headed households were poor. About one third of households with an underemployed head was poor and half when the head was unemployed (almost half of the indigents were self-employed and informal sector workers). About 40 per cent of the poor were older than 50 years, and indigency incidence was worse in this group. Low educational achievement was a decisive factor: 80 per cent of the poor were found in families whose members had less than six years of schooling. About 25 per cent of the poor were engaged in traditional agriculture ( 40 per cent were owners and workers), and 20 per cent in urban informal work, particularly in domestic service. Agriculture, fishing and mining had twice the average national poverty incidence. The persons most likely to be poor, therefore, were living in a rural area outside of the central rural region, and were either owners or workers in agriculture, or were in the informal sector and underemployed; they were either members of a female headed household (usually in an 'informal' family) or older than 50 years of age (IDB, 1994b). In spite of the improvement experienced in the 1990s, there were still poverty pockets in 1993 that required proper targeting and help.

\section{Inequality}

Costa Rica is an ethnically homogenous country, hence inequality is generally the result of factors other than ethnicity, such as sex, location, education and occupation. From the 1950s until the 1970 s there was an improvement in equality; the 1980 s crisis adversely affected some of these gains but, in the early 1990s, Costa Rica still remained one of the most equal countries in the region.

Two series on national income distribution for 1961-90 are summarized in Table 7.9: the first pertains to family income in 1961-88 while the second refers to income of heads of household and salaried employees in 1979-90; the two series are not technically comparable. The bottom of the table also shows the Gini coefficient, nationally for the first series and disaggregated by urban and rural areas for the second series. Distribution of family income generally improved in 1961-71, with the Gini coefficient declining from 0.50 to 0.43 . However, the disaggregation by income decile shows that while the share of the richest decile declined, that of the poorest two deciles also went down slightly. This income was transferred mostly to the middle deciles. The overall income distribution deterior- 
Table 7.9 Distribution of income in Costa Rica, 1961-90

\begin{tabular}{|c|c|c|c|c|c|c|c|c|c|}
\hline \multirow[t]{2}{*}{ Decile } & \multicolumn{4}{|c|}{ Family income } & \multicolumn{5}{|c|}{ Income head of household-salaried employee } \\
\hline & 1961 & 1971 & 1983 & 1988 & 1979 & 1982 & 1985 & 1988 & 1990 \\
\hline First & 2.6 & 2.1 & 1.5 & 1.6 & 2.2 & 2.1 & 1.7 & 1.2 & 1.1 \\
\hline Second & 3.4 & 3.3 & 3.0 & 3.1 & 4.0 & 3.9 & 3.1 & 2.7 & 2.8 \\
\hline Third & 3.8 & 4.2 & 4.1 & 4.3 & 4.9 & 5.5 & 5.3 & 3.9 & 4.3 \\
\hline Fourth & 4.0 & 5.1 & 5.2 & 5.5 & 6.0 & 6.0 & 5.8 & 5.3 & 5.2 \\
\hline Fifth & 4.4 & 6.2 & 6.3 & 6.6 & 7.3 & 7.9 & 6.1 & 6.3 & 6.4 \\
\hline Sixth & 5.4 & 7.5 & 7.5 & 8.1 & 8.3 & 8.5 & 8.1 & 7.7 & 8.1 \\
\hline Seventh & 7.1 & 9.3 & 9.2 & 9.8 & 9.5 & 10.4 & 10.0 & 9.5 & 10.1 \\
\hline Eighth & 9.3 & 11.7 & 11.4 & 12.5 & 12.1 & 11.8 & 12.8 & 12.3 & 12.9 \\
\hline Ninth & 14.0 & 16.2 & 15.1 & 16.8 & 17.3 & 16.0 & 17.4 & 17.0 & 17.2 \\
\hline Tenth & 46.0 & 34.4 & 36.7 & 31.7 & 24.2 & 27.9 & 29.7 & 34.1 & 31.9 \\
\hline Total & 100.0 & 100.0 & 100.0 & 100.0 & 100.0 & 100.0 & 100.0 & 100.0 & 100.0 \\
\hline $\begin{array}{l}\text { Gini } \\
\text { coefficient }\end{array}$ & 0.50 & 0.43 & 0.47 & 0.43 & & $\begin{array}{l}0.328 \\
0.355\end{array}$ & & $\begin{array}{l}0.364 \\
0.358\end{array}$ & $\begin{array}{l}0.345 \\
0.351\end{array}$ \\
\hline
\end{tabular}

${ }^{a}$ All national data. The two series are not technically comparable.

"Family income series is national; heads of household data are for urban and rural.

Sources: Family income: 1961 from ECLAC (1968a); 1971 from Céspedes (1973); 1983 from Trejos y

Elizalde, (1985); 1988 from Baldares (1988). Income Head of Household: 1979 from Aitimir (1984); 1982 to 1990 from ECLAC (1993e). Gini from Baldares, 1988 and ECLAC (1994g). Baldares' help was crucial in putting this table together.

ated between 1971 and 1983 (in the midst of the crisis) as the Gini increased from 0.43 to 0.47 . An improvement occurred in 1983-8 both overall (the Gini declined back to 0.43) and by deciles. In spite of the trend reversal during the crisis, in 1988 the distribution was more equal than it was in 1961.

The second series also shows a change in income distribution in 1979-82 that favoured the middle-income group. The situation clearly deteriorated in 1985, and again in 1988. The Gini coefficient in urban households deteriorated badly in 1982-8 (from 0.328 to 0.364 ) while that of rural households was almost stagnant ( 0.355 and 0.358$)$, hence reversing the inequality by location in favour of rural areas. The situation improved in 1990.

These series suggest that, before and after the crisis, there were income transfers from the richest (and sometimes from the poorest) income groups to the middle group, while during the crisis there were transfers from most groups to the richest group. Data on wages for 1972-94 shows that the average wage declined sharply during the crisis and, despite the recovery, was about the same in 1980 and 1994. On the other hand, the minimum wage was steadily raised after the crisis and by 1993 was significantly higher than in 1980. These trends indicate a government policy to help low income employees.

Inequalities in income distribution have been partly compensated by welfare benefits, as Table 7.10 demonstrates. It shows several welfare programmes, largely geared to the poor, financed by FODESAF, and administered by several public agencies in 1993: non-contributory pensions for the dispossessed (CCSS), nutrition (MEP, MINSA, IMAS), credit and training to generate jobs (Ministry of Labour 
Table 7.10 Distribution of welfare benefits in Costa Rica, 1993

\begin{tabular}{|c|c|c|c|c|c|c|c|}
\hline Quintiles $^{a}$ & Pensions $s^{b}$ & $\begin{array}{l}\text { Food } \\
\text { stamps }\end{array}$ & $\begin{array}{l}\text { School } \\
\text { meals }\end{array}$ & $\begin{array}{l}\text { Milk for } \\
\text { children }\end{array}$ & $\begin{array}{l}\text { Credit and } \\
\text { training }\end{array}$ & $\begin{array}{l}\text { Care of } \\
\text { minors }\end{array}$ & $\begin{array}{l}\text { Housing } \\
\text { aid }\end{array}$ \\
\hline \multicolumn{8}{|c|}{ National } \\
\hline First & 40 & 61 & 40 & 50 & 48 & 31 & 25 \\
\hline Second & 25 & 21 & 23 & 22 & 4 & 32 & 24 \\
\hline Third & 19 & 12 & 18 & 20 & 18 & 22 & 24 \\
\hline Fourth & 15 & 6 & 13 & 7 & 23 & 0 & 13 \\
\hline Fifth & 1 & 0 & 6 & 1 & 7 & 15 & 14 \\
\hline \multicolumn{8}{|c|}{ Urban } \\
\hline First & 29 & 47 & 22 & 32 & 27 & 0 & 19 \\
\hline Second & 27 & 20 & 23 & 11 & 9 & 32 & 23 \\
\hline Third & 25 & 27 & 21 & 47 & 37 & 53 & 26 \\
\hline Fourth & 17 & 6 & 23 & 5 & 9 & 0 & 13 \\
\hline Fifth & 2 & 0 & 11 & 5 & 18 & 15 & 19 \\
\hline \multicolumn{8}{|c|}{ Rural } \\
\hline First & 48 & 71 & 53 & 56 & 63 & 54 & 34 \\
\hline Second & 23 & 22 & 23 & 25 & 0 & 31 & 26 \\
\hline Third & 14 & 2 & 15 & 12 & 6 & 0 & 21 \\
\hline Fourth & 14 & 5 & 6 & 7 & 31 & 0 & 13 \\
\hline Fifth & 1 & 0 & 3 & 0 & 0 & 15 & 6 \\
\hline \multicolumn{8}{|c|}{$\begin{array}{l}\text { "All columns sum to } 100 \text { per cent; a tiny residual group has been added to the lowest quintile in some } \\
\text { nutrition categories. } \\
\text { "Non-contributory pensions paid by social insurance to the dispossessed. } \\
\text { "IMAS aid to poor mostly in informal sector. } \\
\text { Source: Author's elaboration based on IDB (1994b). }\end{array}$} \\
\hline
\end{tabular}

and Social Security), care of minors with problems (National Foundation for Children), and bonuses for housing (Mortgage Bank for Housing). The two programmes that had the most progressive distribution were nutrition and welfare pensions. At the national level, 65 per cent of welfare benefits went to the poorest, although a small proportion of the richest quintile benefited from these programmes. The distribution within rural areas was more progressive than that within urban areas. Out of total beneficiaries of non-contributory pensions, 44 per cent were in indigent households, 15 per cent in poor, and 40 per cent in non-poor; again, the distribution was more progressive in rural areas (IDB, 1994b). Overall, however, the impact of state subsidies to all pensions (including CCSS contributory and non-contributory, and civil servant independent funds) was regressive, because the highest subsidy share went to higher-income civil servants and the smallest share to welfare pensions for the dispossessed (Mesa-Lago, 1994a).

Credit and training were also progressively distributed, and this was true of programmes for care of minors also; these programmes, however, each had only 2 per cent of the total budget. The housing programme, on the other hand, received 33 per cent of the total budget, and its redistributive effect was either 
very small or neutral. The allocation of the housing subsidy was bigger to urban areas (55.4 per cent) than to rural areas ( 44.6 per cent), but the redistributive impact was higher within the latter than within the former. Nationally, 27 per cent of the housing subsidy went to the richest two quintiles. It has been argued that the crisis affected salaried workers and the middle class more than nonsalaried workers such as small farmers (ILO, 1992b) but our analysis does not support that assumption.

Several studies have been conducted on the redistributive impact of health care in Costa Rica. The first, in 1978, showed that the overall effect was progressive, and was much more so in the MINSA component (geared more to the rural and urban poor) than the CCSS component. A household survey in 1982 measured the impact of state subsidies to health care services on family income distribution: nationally the latter increased 61 per cent in the poorest decile, but rose only 2.4 per cent in the richest quintile (Mesa-Lago, 1989,1992). The author could find neither an estimation of the impact of health care nor of all welfare programmes on income distribution for the early 1990s.

\section{Policies, institutions and resources}

The historical, geographic, demographic and political factors which may have contributed to the exceptional performance of Costa Rica in social development were discussed above. In this section, a closer examination of policies, institutions and resource use in the social sectors will be undertaken in order to shed further light on this phenomenon.

\section{Institutional arrangements}

We will discuss herein the social sector roles and responsibilities of state agencies and the non-public/private sector, the relations between the two, and the impact of these institutional arrangements on population coverage, equity and efficiency of resource use.

The role of the public and the private sectors in social development

Costa Rica is a market economy but, since the 1950s, the state has played an increasingly important role in the economy and in the provision of social services. The crisis and structural adjustment reduced the state role in the economic realm, through privatization of public enterprises, price liberalization, deregulation, cuts in public employment and so forth. Still, in 1992 Costa Rica ranked second in Latin America in the proportion of its urban EAP employed in the public sector (25 per cent), and third, in 1993, in its share of public expenditures in GNP: 26.7 per cent - comparable to the 26.3 per cent share in 1980 prior to the crisis.

Although the crisis adversely affected social services, structural adjustment programmes did little to reduce the predominant role of the state in this area. The state overwhelmingly continues to be the provider of social services. However, the private sector has expanded its scope somewhat since the 1980s. The major role for the private sector is in education, followed by health care. There is a very 
small but growing sector of private pension providers, but very little private participation in anti-poverty programmes.

The predominant state role in key social areas, such as health care and social security, has been justified by a Costa Rican official on several grounds: (a) immunization, prevention and environmental protection are 'public goods' that benefit even those who do not pay for them, and the market can not be an efficient provider of these services (i.e., it is not interested in prevention); (b) there are positive and negative externalities which the market cannot take into account; (c) price is not the best allocation mechanism because those who buy these services pursue individual instead of societal interests; (d) public solidarity is essential in social security, in order to pool risks and subsidize those who are unable to pay (commercial insurance companies do not accept those who cannot afford the premium, and try to exclude those afflicted by high risks); and (e) suppliers can induce demand and exercise certain mono-oligopolistic control on quantity and prices of some goods and services, hence, if such suppliers are commercial they can maximize their profit at the cost of the users (Durán, 1993). It is not the intention of this study to analyse these arguments (some of which are debatable); they are presented here to illustrate the official view.

\section{The public sector}

In addition to playing a predominant role in social development, the Costa Rican state, through multiple agencies, has three important features: (a) an extensive social service network with a long period of operation; (b) strong interaction among most agencies within the public social network; and (c) establishment of goals concerning universalization and equity.

a. Extensive social service network with a long history. We have noted that some of the key public social services in Costa Rica were established quite early - for instance, compulsory primary education and public secondary schools began in the late nineteenth century, monopoly of insurance by INS (including employment injury) in 1924, and the Ministry of Health was established in 1927. Social security did not arrive until 1941, 10 or 15 years after the pioneer countries but, at that time, Costa Rica was quite undeveloped and lacked a strong union movement. President Rafael Calderón Guardia (a physician) decided to introduce social security early to avoid the socio-political instability he had observed in other more developed Latin American countries (Mesa-Lago, 1989). The revolution of 1948 led to the subsequent development of a dominant (although not hegemonic) social democratic party, and a strong interventionist state. Both pushed for universalization of primary education beginning in the 1950s, and of social security in the 1960s and 1970s. The integration of all hospitals in one single institution (CCSS), in 1974-8, and their opening to the dispossessed is unique in Latin America, with the exception of Cuba. Antipoverty programmes were created early: IMAS in 1970 and FODESAF in 1974, long before social safety nets became fashionable in Latin America (the first, in Bolivia, began in 1986). The unemployed are covered by health care and, if poor, are entitled to welfare pensions. 
Costa Rica's social achievements are even more remarkable considering that the country was predominantly rural, agricultural and poor, and that prior to World War II the nation ranked in the bottom half of the region concerning social indicators (Mesa-Lago, 1996b).

Before the crisis of the 1980s, the Costa Rican state had, therefore, developed an extensive public social network made up of multiple programmes, a few directly administered by the central government (MINSA, MEP, FODESAF) but most of them organized as autonomous institutions (CCSS, ICAA, IMAS, INS). This network covered practically all social risks and provided social services to almost all the population, even people located in remote rural areas. Rudimentary indicative planning began in Costa Rica in the 1950s, and the first formal planning office was established in 1963. Since then, there have been medium-term plans (usually coinciding with presidential terms) and virtually all of them have addressed crucial social issues. For instance, the 1965-8, 1969-72 and 1972-8 plans included the extension of CCSS coverage and integration of hospitals (a sectoral National Health Plan in 1971-80, supported the expansion of MINSA primary health care to remote rural areas and marginalized urban areas); the 1982-6 plan began the integration of some health care services of CCSS and MINSA; the 1986-90 plan attempted the creation of a National Health System and decentralization of health services; the 1990-94 plan had a programme to generate productive employment and social protection; and the current $1994-8$ plan has a national strategy to eliminate poverty (Mesa-Lago, 1996b).

b. Interaction between agencies within the public network. Health care coverage involves two major agencies: (a) MINSA, which is in charge of general policy guidelines and supervision, prevention, environmental and epidemiological control, nutrition, family planning, day care centres, and primary health care (both preventive and curative) to marginalized rural and urban populations; and (b) CCSS, which basically provides curative care although it also has some preventive functions. The CCSS covers the insured, pensioned and non-insured dispossessed, as well as all their dependent family. Smaller agencies manage sewerage, rehabilitation, food stamp, and school meal programmes.

Although there is a clear division of functions between MINSA and CCSS, as well as some integration of their facilities and services at the local level, all attempts to integrate the two agencies into an unified national health care system have so far failed. Each institution continues to function with its own facilities, personnel and budgets (although some new facilities will be integrated), and such duality results in overlapping and some waste; for instance the two institutions combined cover 135 per cent of the total population. In 1993, after three years of negotiations, CCSS and MINSA agreed on a new approach to health care administration which provided that MINSA would be the director, regulator and supervisor of the system, while the CCSS would become the only provider of an integral health care programme, combining primary and curative care, for all the population, with priority targeting for the most vulnerable. The plan also called for the CCSS to strengthen its co-operation with the private sector and for a process of 
administrative decentralization and regionalization, with freedom by the population to select providers, and transparency in terms of the origin and destination of resources. The change in the party in power in mid-1994 seems to have slowed down the implementation of this agreement (MIDEPLAN, 1992; Mora and Valverde, 1993; Saenz, 1994; Sojo, 1994).

Pensions (OADS) are mainly administered by CCSS through its contributory and non-contributory programmes; the latter covers the non-insured dispossessed. IMAS determines the condition of indigency through funds also provided by FODESAF. With its non-contributory (welfare) programmes on health care and pensions, the CCSS is one of the very few institutions in the region that combines social insurance and social assistance (Mesa-Lago, 1994a). There were 20 independent pension funds for civil servants, with their own legislation, entitlement conditions and financing; the majority of them were administered by the Ministry of Labour and Social Security and the rest by autonomous institutions. In 1992, a law 'closed' 17 of those funds and incorporated them into the CCSS, and a compromise agreement was reached with the teachers' fund to gradually incorporate its members. In 1996 only the funds for the Legislative and Judiciary branches remained independent (Mesa-Lago, 1996a).

Pre-school, primary and secondary (both formal and techno-vocational) education is administered by MEP, which also receives and transfers fiscal funds to higher education, sets the overall educational policy, and supervises the system. FODESAF transfers funds to some special programmes administered by MEP, including literacy and adult education. The two public universities and the public technological institute are autonomous, and MEP has no control over their resources.

Anti-poverty programmes are mostly concentrated in FODESAF, which does not administer them, but transfers funds to both state ministries and autonomous institutions. There are too many institutions and programmes dealing with poverty (38 in 1994), as well as lack of integration and targeting, all of which provokes overlapping and waste of resources.

In summary, the public social network is quite wide and comprehensive, and there is significant interaction among its agencies, but it suffers from an excessive number of institutions, duplication, and centralization.

c. Establishment of goals on universalization and equity. The government established goals on universalization, solidarity and equity for the public social network, but achievement of those goals have not been equal in all the major programmes: health care and primary education have been the most successful, followed by pensions and secondary education. Anti-poverty programmes have helped to attain these goals but still there are population pockets, albeit small, that are either excluded or receive low-quality services.

Universalization of health care began with a constitutional amendment in 1961 which gave the government ten years to provide full coverage to all the population; an additional push in the 1970s led to virtually universal coverage by 1980 . Several groups often excluded from legal coverage and real access to health care in 
other countries have been incorporated in Costa Rica: domestic servants, employees of microenterprises and of small employers, the self-employed, and unpaid family workers. Coverage of the first two groups is mandatory, while the last three groups can join voluntarily; all five groups must pay contributions. Non-insured people who are dispossessed are covered without having to make contributions, and their health care is free. Other countries in Latin America with similar legal arrangements have not been as successful as Costa Rica in achieving true universalization. Part of the explanation for this lies in the financing system to be discussed here) and part in the economic, labour and social peculiarities of Costa Rica that were discussed above.

Costa Rica has been much more successful in providing health insurance coverage to self-employed workers than have other countries in the region. Elsewhere, a self-employed worker must pay the percentage contribution normally paid by both the worker and the employer - typically totalling close to 15 per cent of income. In Costa Rica, on the other hand, the average contribution effectively paid by the self-employed is 5.8 per cent, and a majority of them only contribute the minimum 5 per cent, which is smaller than the salaried insured contribution. Furthermore, the contribution is a percentage of declared income, and many selfemployed underdeclare their income (salaried workers in microenterprises often register themselves as self-employed or indigent to procure cheaper or free coverage). Although these rules and practices have created financial problems for the CCSS, they have certainly facilitated universal coverage. In addition, if the self-employed worker's (or seasonal worker's) earnings are lower than the minimum wage, the state is obligated to make up the shortfall in the contribution. Finally, the CCSS has promoted special agreements with associations of selfemployed, peasants, co-operatives, and unions, which are responsible for collecting their members' contributions and transferring them to the CCSS (Mesa-Lago, 1994a).

The coverage of the OADS (pension) programme is much lower: 43 per cent of the EAP is neither covered by the CCSS contributory programme nor by the 20 formerly independent pension funds for civil servants. Those excluded tend to be the very young and old, the poor, uneducated, and those working in agriculture or in the urban informal sector (self-employed, domestic servants, employees in microenterprises). The poor are entitled to a CCSS-OADS welfare pension (the non-poor often qualify for it too, due to inefficient means testing). In 1994 the welfare pension minimum was only one-half of the contributory pension minimum, and was insufficient to cover basic needs; however, anti-poverty programmes help this group. More unequal than the two OADS programmes within the CCSS were the entitlement conditions and benefits provided by many of the privileged independent funds for civil servants (and state subsidies to that group); those inequalities, nevertheless, are being gradually eliminated with the incorporation of the civil servants in the CCSS-OADS programme. The remaining two independent groups (Legislative and Judiciary) represent salient inequalities in an otherwise remarkably equal pension system; they should also be incorporated into CCSS. Although universality and equity in pensions are not as good as in health 
care, once again, Costa Rica is among the top two or three Latin American countries in this matter.

As discussed above, although Costa Rica ranks among the top three or four countries in the region concerning educational universality and equality, more specific targeting of rural areas and disadvantaged children and improvements in techno-vocational secondary schools are needed to solve the remaining problems of low and unequal access in this area.

Costa Rica has the lowest poverty incidence and the second best income distribution in the region, testimonies of its progress in achieving equity. Antipoverty programmes have partially compensated for existing gaps but some of them (nutrition, welfare pensions) have been more beneficial to rural areas and the poor than others (particularly housing programmes, which have favoured the urban sector). Still, part of the resources of these programmes go to the non-poor. These flaws reinforce the need for better targeting, integration and efficiency in the administration of social programmes.

\section{The private sector}

The remarkable development of public social services in Costa Rica has left little room for the private sector. There is scanty information on its precise size in general and by specific areas, and even less is known of its users, costs, efficiency and so forth.

In health care, the private sector managed less than 2 per cent of the total number of hospital beds in 1982-7. Some non-insured people who have the resources use CCSS facilities and services, paying user fees; for instance 2 per cent of dental consultations in the CCSS in 1986 were for private patients. A household survey taken in 1983 revealed that 64 per cent of the population who were sick had sought medical consultation and 14.6 per cent of these did so in the private sector, thus only 9.3 per cent of the sick resorted to a private physician or clinic (Mesa-Lago 1992).

So far the most important expansion of the private sector is its collaboration with the CCSS-SM with the aim of reducing the latter's costs, increasing its efficiency, and improving the quality of its services. The enterprise physician (EP) programme began in the 1970s: the enterprise hires a physician and a nurse and provides an office, while the CCSS supplies support services; in 1993 there were 1,000 participating enterprises that provided 7 per cent of all national consultations. The co-operative programme began at the end of the 1980s: a co-operative or local autonomous organization signs a contract with CCSS and MINSA, which supply the co-op with a fully equipped clinic for the term of the contract, and pay a fixed annual sum plus a monthly sum per insured. The co-op, in turn, provides primary health care, curative care, medicines, etc. for both insured and indigents, and is responsible for maintaining the clinic, hiring the personnel and buying the needed inputs. Users select a physician working at the co-operative and do not pay. In 1994 there were three co-operatives in operation with a combined total of 142,000 users, or 6 per cent of the total number of insured at CCSS-SM. 
The EP programme is not accessible to the poor, while the co-ops are. Both have had some success in reducing costs and increasing user satisfaction. However, they also have some problems. The very slow expansion of these and other similar private-public partnership programmes may be either the result of resistance from the CCSS bureaucracy, opposition to privatization, high funding costs needed for co-ops, or actual costs being higher than reported (Quirós, 1991; Jaramillo, 1993; Mesa-Lago, 1992, 1994b; Mora and Valverde, 1993; Sojo, 1993; Güendel and Trejos, 1994; CCSS, 1995b).

Private pension programmes are recent and limited to a tiny fraction of the labour force. They are voluntary and their goal is to provide a supplementary pension (to that of CCSS-OADS) based on a fully-funded system with individual accounts. The largest programmes, so far, cover civil servants with high salaries employed in powerful autonomous institutions, such as the National Bank and INS; the two combined have 30,000 insured in a supplementary pension programme. There has been a proposal for a mixed pension system that would combine the CCSS-OADS programme paying a basic pension, based on partialfunding, and a supplementary pension programme, fully funded and administered by private institutions (Cartín, 1991). One proposed reform is considering the creation of a mandatory supplementary pension programme administered by private as well as public institutions (Durán, 1993).

The private education sector was very small in 1990-92: it served 13 per cent of students in the primary level, 6.5 per cent in the secondary level (limited to formal day-time schools), and 18 per cent in the higher level. The latter level appears to be the one expanding fastest: in 1986-90 enrolment in public universities increased 6 per cent but private enrolment jumped 45 per cent (there was only one private university in operation prior to 1986 , but seven were established in 1986-90). The cost of annual tuition in public universities ranges from US $\$ 20$ to $\$ 200$, and 80 per cent of the students receive free tuition. The average tuition cost in private universities is $\$ 1,200$ and goes up to $\$ 4,000$. The highest income groups send their children to study in foreign universities, hence, the market for domestic private higher education appears to be the upper middle-income group, particularly those connected with private businesses (IDB, 1994b). The author could not find data on costs and efficiency of private schools at the primary and secondary levels. These facilities are obviously not accessible to lower income groups and so far do not seem to present a challenge to the public sector.

\section{Amount and efficiency of resource allocation}

\section{Overall allocation by programme}

A complete historical series on public social expenditures as a percentage of GDP in 1970-94 has been constructed in Table 7.11, based on data from each of the major three components: health, social security and education. ${ }^{3}$ The social share of GDP increased from 8.9 per cent in 1970 to 15.5 per cent in 1980 , one of the highest in the region; the share declined to 10.8 per cent in 1982, the worst year in the crisis, and rose thereafter to reach 15.6 per cent in 1993 , slightly above the 
Table 7.11 Major public social expenditures as percentage of GDP in Costa Rica, 1970-94

\begin{tabular}{|c|c|c|c|c|c|c|c|}
\hline \multirow[t]{2}{*}{ Year } & \multicolumn{3}{|c|}{ Health } & \multicolumn{2}{|c|}{ Social security $\operatorname{CCSS} S^{b}$} & \multirow[t]{2}{*}{ Education } & \multirow[t]{2}{*}{ Total $^{d}$} \\
\hline & $\begin{array}{l}\text { CCSS: sickness, } \\
\text { maternity }\end{array}$ & $\begin{array}{l}\text { Rest } \\
\text { health }\end{array}$ & $\begin{array}{l}\text { Total } \\
\text { health }\end{array}$ & Pensions & Total & & \\
\hline 1970 & 1.9 & 3.2 & 5.1 & 0.4 & 2.3 & 3.4 & 8.9 \\
\hline 1971 & 2.3 & 4.0 & 6.3 & 0.4 & 2.7 & & \\
\hline 1972 & 2.6 & 3.9 & 6.5 & 0.5 & 3.1 & 5.2 & 12.2 \\
\hline 1973 & 2.6 & 3.6 & 6.2 & 0.8 & 3.4 & 5.3 & 12.3 \\
\hline 1974 & 2.7 & 3.5 & 6.2 & 0.9 & 3.6 & 5.4 & 12.5 \\
\hline 1975 & 3.1 & 4.0 & 7.1 & 0.8 & 3.9 & 5.5 & 13.4 \\
\hline 1976 & 3.4 & 3.0 & 6.4 & 0.9 & 4.3 & 5.9 & 13.2 \\
\hline 1977 & 3.9 & 2.5 & 6.4 & 0.7 & 4.6 & 5.5 & 12.6 \\
\hline 1978 & 4.6 & 2.1 & 6.7 & 0.8 & 5.4 & 6.0 & 13.6 \\
\hline 1979 & 5.2 & 2.4 & 7.6 & 0.9 & 6.1 & 6.2 & 14.7 \\
\hline 1980 & 5.5 & 2.5 & 8.0 & 1.0 & 6.5 & 6.2 & 15.5 \\
\hline 1981 & 4.9 & 1.9 & 6.8 & 0.9 & 5.8 & 5.0 & 13.5 \\
\hline 1982 & 4.0 & 1.7 & 5.7 & 0.9 & 4.9 & 4.2 & 10.8 \\
\hline 1983 & 4.2 & 2.0 & 6.2 & 1.3 & 5.5 & 4.6 & 12.1 \\
\hline 1984 & 4.4 & 1.9 & 6.3 & 1.4 & 5.8 & 4.2 & 11.9 \\
\hline 1985 & 4.6 & 2.0 & 6.6 & 1.6 & 6.2 & 4.1 & 12.1 \\
\hline 1986 & 4.4 & 2.5 & 6.9 & 1.9 & 6.3 & 4.3 & 13.1 \\
\hline 1987 & 4.4 & 2.4 & 6.8 & 2.0 & 6.4 & 6.0 & 14.8 \\
\hline 1988 & 4.9 & 2.0 & 6.9 & 2.1 & 7.0 & 4.6 & 13.6 \\
\hline 1989 & 5.5 & 2.0 & 7.5 & 2.1 & 7.6 & 4.4 & 14.0 \\
\hline 1990 & 5.8 & 1.8 & 7.6 & 2.2 & 8.0 & 4.9 & 14.7 \\
\hline 1991 & 5.4 & 1.7 & 7.1 & 2.2 & 7.6 & 4.7 & 14.0 \\
\hline 1992 & 5.2 & 1.5 & 6.2 & 1.6 & 6.8 & 5.7 & 14.0 \\
\hline 1993 & 5.7 & 1.8 & 7.5 & 2.3 & 8.0 & 5.8 & 15.6 \\
\hline 1994 & 5.6 & 1.8 & 7.4 & 1.8 & 7.8 & 5.8 & 15.4 \\
\hline
\end{tabular}

"Ministry of Health, the National Insurance Institute (INS) monetary expenditures on occupational hazards, the Costa Rican Institute of Aqueduct and Sewerage (ICAA), university and municipal services. ${ }^{b}$ Contributory and non-contributory (welfare) pensions; excludes civil servants funds; total includes pensions and sickness-maternity (column 1).

'Only central government; there are two series that break in 1983.

"Sum of columns 3,4 and 6 .

Sources: Social security and health from CCSS (1976 to 1991a, 1990b to 1995b, 1995c); Sanguinetty (1988a); Mesa-Lago (1989, 1990, 1992, 1994b); Jaramillo (1993); IDB (1994b); Durán and González (1994); MS (1995). Education from IMF (1980a to 1994a, 1990b to 1995b); MEP (1993).

1980 level. Only Argentina, Uruguay and Panama had higher shares in that year (World Bank, 1995a, 1995b; ECLAC, 1995g). As real GDP recovered and steadily grew in the second half of the $1980 \mathrm{~s}$ and first half of the 1990s, the rising percentage of social expenditures in GDP was an indication of an even greater effort to expand the social sector in Costa Rica.

The three major social programmes have been separated in Table 7.11 to show their individual importance. Health expenditures combine those of social security (CCSS-SM), the Ministry of Health (MINSA), the National Insurance Institute (INS, but only monetary expenditures as health care is largely provided through CCSS 
and MINSA facilities), the Aqueduct and Sewerage Institute (ICAA), municipalities and universities, as well as transfers from other programmes. The third column of Table 7.11 shows that public health expenditure was the highest of the three social programmes. It peaked at 8 per cent of GDP in 1980, declined sharply in 1981-2, and rose gradually thereafter.

The two social security columns refer to pension expenditure (OADS contributory and non-contributory programmes), and total CCSS expenditures (adding CCSS-SM expenditures from the first column). Expenditures on pensions were very low in the early 1970 s, but gradually rose to reach 2.3 per cent of GDP in 1993. The CCSS (SM plus OADS) is the single most important social institution in Costa Rica, spending much more than all other health care and educational institutions combined. Its total share of GDP grew steadily to reach 6.5 per cent in 1980 , declined to 4.9 per cent in 1982, but rose thereafter, peaking at 8 per cent in 1990 and 1993, well above the 1980 level.

The share of education expenditure in GDP was the second largest after health care, and shows a similar pattern to that of heath care and social security. It increased steadily until 1980, declined during the crisis years, and recovered gradually thereafter, reaching 5.8 per cent in 1994 .

Total central government expenditures as a proportion of GDP in Costa Rica are among the highest in the region (over 26 per cent in both 1980 and 1993), and were higher than those of Japan, the United States and Canada. As a percentage of total central government expenditures, Costa Rica's social share (health, education, social security/welfare and housing) reached 70 per cent in 1982, declined to 58 per cent in 1985 and rose again to 67 per cent in 1992 (see Table 7.12). It should be noted that the social share kept expanding in the worst years of the crisis (1981-2), and that in 1993 Costa Rica did not have any expenditures on defence (World Bank, 1995a).

The distribution of the social share of GDP by the four major programmes in 1972-93 is also presented in Table 7.12. All programmes felt the effect of the crisis, as social expenditures dropped from 1983 to 1986. In addition, the data show that there has been a shift in resources from education and housing towards social security and, to a lesser extent, health (outside of social security).

In terms of annual real per capita social expenditures (measured in 1985 US dollars) Costa Rica ranked fourth or fifth in Latin America in 1980-91. The averages were: $\$ 251$ in 1980-81 (the beginning of the crisis), $\$ 231$ in 1983 (the worst of the crisis and the beginning of the recovery) and $\$ 261$ in 1990-91 (during the recovery) (ECLAC, 1995g).

\section{Distribution and efficiency of resource use within each programme}

In this section we analyse the allocation of resources and expenditures within each of the four major social programmes: health care, education, social security, and poverty.

a. Health care. In 1990, Costa Rica's public expenditures on health care as a percentage of GDP was the highest in Latin America and well above that of 
Table 7.12 Percentage distribution of central government expenditures by social programmes in Costa Rica, 1972-93

\begin{tabular}{|c|c|c|c|c|c|c|c|}
\hline \multirow[t]{2}{*}{ Years } & \multirow{2}{*}{$\begin{array}{l}\text { Social } \\
\text { security" }\end{array}$} & \multirow{2}{*}{$\begin{array}{l}\text { Health } \\
\text { care }^{b}\end{array}$} & \multirow[t]{2}{*}{ Education } & \multirow{2}{*}{$\begin{array}{l}\text { Housing, } \\
\text { etc. }\end{array}$} & \multicolumn{2}{|c|}{ Sub-totals } & \multirow[t]{2}{*}{ Total } \\
\hline & & & & & Social & Non-Social & \\
\hline 1972 & 23.1 & 3.5 & 26.7 & 2.1 & 55.4 & 44.6 & 100.0 \\
\hline 1973 & 23.6 & 2.9 & 25.7 & 5.2 & 57.4 & 42.6 & 100.0 \\
\hline 1974 & 22.2 & 3.9 & 27.0 & 2.4 & 55.5 & 44.5 & 100.0 \\
\hline 1975 & 25.1 & 4.3 & 27.3 & 1.7 & 58.4 & 41.6 & 100.0 \\
\hline 1976 & 24.9 & 4.5 & 26.2 & 1.1 & 56.7 & 43.3 & 100.0 \\
\hline 1977 & 23.5 & 3.3 & 28.5 & 2.1 & 57.4 & 42.6 & 100.0 \\
\hline 1978 & 29.7 & 3.8 & 25.7 & 2.0 & 61.2 & 38.8 & 100.0 \\
\hline 1979 & 30.2 & 2.4 & 24.8 & 2.6 & 60.0 & 40.0 & 100.0 \\
\hline 1980 & 30.8 & 5.0 & 24.6 & 2.2 & 62.6 & 37.4 & 100.0 \\
\hline 1981 & 36.0 & 4.0 & 23.7 & 2.3 & 66.0 & 34.0 & 100.0 \\
\hline 1982 & 37.7 & 6.3 & 22.6 & 2.9 & 69.5 & 30.5 & 100.0 \\
\hline 1983 & 34.1 & 2.8 & 19.4 & 2.7 & 59.0 & 41.0 & 100.0 \\
\hline 1984 & 30.0 & 5.7 & 18.4 & 5.8 & 59.9 & 40.1 & 100.0 \\
\hline 1985 & 35.3 & 2.2 & 18.8 & 1.8 & 58.1 & 41.9 & 100.0 \\
\hline 1986 & 36.9 & 1.7 & 16.2 & 7.4 & 62.2 & 37.8 & 100.0 \\
\hline 1987 & 28.8 & 2.3 & 22.1 & 9.1 & 62.3 & 37.7 & 100.0 \\
\hline 1988 & 34.0 & 4.0 & 18.6 & 1.5 & 58.1 & 41.9 & 100.0 \\
\hline 1989 & 35.7 & 4.8 & 17.0 & 3.5 & 61.0 & 39.0 & 100.0 \\
\hline 1990 & 35.0 & 5.0 & 19.0 & 1.1 & 60.1 & 39.9 & 100.0 \\
\hline 1991 & 37.9 & 6.4 & 19.1 & 0.7 & 64.1 & 35.9 & 100.0 \\
\hline 1992 & 36.8 & 6.3 & 23.9 & 0.3 & 67.3 & 32.7 & 100.0 \\
\hline 1993 & 33.3 & 5.7 & 22.3 & 0.3 & 61.6 & 38.4 & 100.0 \\
\hline
\end{tabular}

the three closest countries (ECLAC, 1995b; UNDP, 1995). But the distribution of expenditures within the health sector has changed over time, and was adversely affected by the crisis of the1980s.

Table 7.11 indicates that, in 1970, the CCSS-SM accounted for about one-third of total health expenditures and other health programmes accounted for twothirds, but with the integration of all hospitals to the CCSS in the 1970s, such proportions were reversed. In 1970, the two curative institutions - CCSS-SM and INS - accounted for 44 per cent of total health expenditures, while the two preventive institutions - MINSA and ICAA - spent 56 per cent. In 1980 the respective proportions were 74 per cent and 26 per cent, and by 1984 the curative-preventive gap had expanded to 84 per cent and 17 per cent. From 1980 to 1993, real expenditures on curative health care grew substantially, while those of MINSA declined by 28 per cent. Expenditures of the curative institutions grew because most of their revenue is generated by payroll contributions, while MINSA suffered drastic cuts in the central government budget allocation. As a result of 
changes in expenditures and financing, coverage (or at least the quality) of primary health care for marginal urban and rural groups deteriorated, and immunization against certain diseases (e.g., measles, tuberculosis) declined. Construction, maintenance and renovation of equipment in MINSA was virtually paralysed in the 1980s (Mesa-Lago, 1992; Mora and Valverde, 1993).

In 1985, the CCSS-SM spent six times more per capita on health care than MINSA, a disparity that could be partly explained by two factors: (a) a shift in the pathological and morbidity profile toward diseases which are more complex and costlier to treat; and (b) the different nature of the services provided by each of these two institutions: CCSS's curative services are capital intensive and require more expensive installations, equipment and personnel than MINSA's preventive and primary care services. Still the proportion of total health care expenditures going to preventive medicine in 1985 was less than one-tenth of that going to curative medicine. A transfer of some resources from the latter to the former would be an efficient step. Another reason for higher costs in CCSS are some inefficiencies in hospital administration, as well as excess and high-cost personnel.

The number of hospitals (all operated by CCSS) declined slightly in 1973-87; conversely the number of CCSS clinics and MINSA health posts increased sevenfold during that period, while MINSA mobile units jumped 15 times. The expansion of the physical plant was impressive on the primary care levels, which was the proper policy to follow (Mesa-Lago, 1992).

Hospital efficiency also improved steadily in 1973-94, as documented in Table 7.13. Hospital bed occupancy increased from 71.5 to 81 per cent, while the average days of stay diminished from 9.4 to 5.7 - both levels are now among the best in the region. The changes described above, combined with the reorganization of infant medical care and the decline in the birth rate, allowed, in 1973-92, a small reduction in both the number of hospitals (from 33 to 29) and in the ratio of hospital beds per 1,000 inhabitants - from 4 to 2.2 (Table 7.2; CCSS, 1992b). Population growth over this period, as well as the stagnation in hospital

Table 7.13 Health care and administrative efficiency in CCSS in Costa Rica: 1973-94

\begin{tabular}{|c|c|c|c|c|c|c|c|c|}
\hline Efficiency indicators & 1973 & 1979 & 1982 & 1987 & 1989 & 1990 & 1992 & 1994 \\
\hline \multicolumn{9}{|l|}{ Health Care } \\
\hline Hospital bed occupancy $(\% / \%)$ & 71.5 & 72.0 & 75.3 & 77.6 & 78.9 & 76.7 & 80.8 & 81.1 \\
\hline Average days of stay & 9.4 & 7.2 & 7.2 & 6.4 & 6.2 & 6.0 & 6.4 & 5.7 \\
\hline Consultations (annual, per capita) & 2.7 & 3.5 & 3.4 & 3.1 & 3.1 & 2.7 & 2.8 & 2.9 \\
\hline \multicolumn{9}{|l|}{ Administration } \\
\hline Expenditures in total $(\%)$ & $8.4^{\prime \prime}$ & $6.9^{\prime}$ & $7.3^{\prime \prime}$ & 3.9 & 4.1 & 4.0 & 4.1 & 3.9 \\
\hline Employees (x 1,000 insured) & & $13.0^{\circ}$ & 12.6 & 10.4 & $8.8^{\prime}$ & 8.5 & 8.2 & 8.2 \\
\hline \multicolumn{9}{|c|}{$\begin{array}{l}\text { "Fundamentally CCSS hospitals } \\
\text { "1975; } 1980 ; \text { “ } 1981 ; " 1988 \\
\text { Somrc's: Author's calculations based on CCSS (1976 to 1991a, 1990b to 1995b); Mesa-1.ago (1992). }\end{array}$} \\
\hline
\end{tabular}


infrastructure during the crisis, also contributed to these declines. Efficiency can still be further improved: occupation rates in children's hospitals and MINSA health centres remain low.

Although there has been remarkable progress in the co-ordination of CCSS and MINSA and there is a general division of functions between them, duplication of facilities and services is still a problem. MINSA has no effective power to design and enforce health policies, as the bulk of health resources goes to the CCSS. The latter's emphasis on curative and specialized medicine increases its costs, while MINSA has insufficient resources to adequately perform its functions. The primary care units have relatively low resources, which leads to a concentration of outpatient consultation in hospitals and increases costs. Physicians do not honour the legal hour daily work schedule, and many of them only work from 2 to 4 hours a day; paramedic personnel is scarce relative to physicians. In 1992, expenditures of peripheral hospitals were very high, and costs of identical consultations varied as much as 100 per cent among the three major hospitals; administrative costs of clinics were higher than those of hospitals. The physical plant and equipment was only partly used daily, and there were no incentives to improve the quality of services (IDB, 1994b; Sojo, 1994).

b. Education. In 1980, before the crisis, Costa Rica's public education expenditure as a percentage of GDP ( 6.2 per cent) was higher than the averages for the world (5 per cent) and Latin America (3.9 per cent). In 1985, when the country was just coming out of the crisis, this percentage had declined to 4.1 per cent. In 1992 , during the recovery, Costa Rica's education expenditure rose again to 5.7 per cent of GDP (UNESCO, 1994).

Unfortunately, the recovery has not helped all educational levels evenly. It should be recalled that, in spite of its impressive gains, inequalities remain in Costa Rica's educational system. In 1980 - prior to the crisis - the shares of the three educational levels in total expenditures were: 35 per cent in pre-school and primary, 24 per cent in secondary (17 per cent in formal and 7 per cent in technovocational), 37 per cent in higher, and 4 per cent in administration. In 1986 - after the crisis - the distribution had become more unequal: 33 per cent in the first level, 20 per cent in secondary (14 per cent formal and 6 per cent technovocational), 45 per cent in the higher level and 2 per cent in administration. The reason for the expanding gap was that the Ministry of Education (MEP) budget was dramatically cut, but the proportion that was assured to the university was protected by the Constitutional mandate.

Problems of efficiency and quality of education pre-dated the crisis, when resources were abundant. In 1980, before the crisis, 97 per cent of the MEP budget was in current expenditures and almost two-thirds of that was spent in salaries and fringes, while less than 1 per cent was allocated to goods and services. As the crisis worsened, an even higher proportion of the budget went to salaries (due to strong union pressure) and almost nothing was left to other crucial needs; but in 1985-6 the situation became untenable and real salaries were allowed to erode (explaining the drop of the educational share in GDP in those years). The salary cut prompted 
teachers to take early retirement, move to other jobs, and decrease both the time devoted to education (in order to search for additional income), and their general labour effort. In order to compensate for the salary cut, the government reduced both the number of school days and daily hours, and became more lax in enforcing teachers' obligations. Substitute teachers with lower skills were hired and training of teachers diminished due to lack of resources and incentives. In urban marginal areas whose population rapidly increased, multiple school shifts (with shorter hours) were introduced, and isolated rural areas became neglected. Evaluation of performance was drastically curtailed or was eliminated altogether due to severe scarcities of supervisors and funds for transportation. Lack of textbooks, paper, pencils and other school materials, as well as physical plant deterioration (including lack of electricity) aggravated those problems. As a result of all of the above, productivity and quality of education sharply declined (Aguilar, 1990; IDB, 1994b).

Higher education, protected by the constitutional umbrella, performed relatively better than the two lower levels, but still faced problems which pre-dated the crisis and were worsened by it. Two-thirds of staff and students in universities are concentrated in the humanities (literature, philosophy, education, law) and the social sciences, while the remaining one-third is in scientific and technological careers (including agricultural sciences). Such disciplinary composition was not conducive to development, but mainly trained bureaucrats for public jobs. Twothirds of all university graduates were employed by the state, with the enticement of low risks, job safety and early retirement with a generous pension (for many years average salaries in the public sector were higher than in the private sector too). But structural adjustment forced a cut in public employment and the university ceased to be the channel for securing a golden job. Strong unionization of university staff allowed an increase in their ranks and pay at the cost of dwindling numbers of and incentives for professors. Only 10 per cent of the higher education budget was allocated to research, there was virtually no co-operation with the private sector, and little or no opportunities existed for internships and practical training. The public universities have significantly reduced requirements for entry (96.5 per cent passed the examinations at the University of Costa Rica in 1987 although the proportion was cut to 77 per cent in 1990) thus sacrificing quality for quantity (Sanguinetty, 1988b; IDB, 1994b).

c. Social security. Within the CCSS, the two most progressively distributed programmes are the non-contributory (welfare) programmes of the OADS and SM. The former's share in total CCSS expenditures rose from 3.5 per cent in 1982 (in the midst of the crisis) to 5 per cent in 1984; as the recovery ensued, the OADS non-contributory share declined to a trough of 2.8 per cent in 1992 but grew again to 4.4 per cent in 1994. We lack disaggregated data on the SM non-contributory expenditures, but data on the proportion of indigents entitled to free health care show that, as the crisis worsened, the proportion increased from 26 to 32.5 per cent (1980-82), and as the crisis abated (and so did poverty) the proportion diminished to 18.8 per cent in 1994 (based on CCSS, 1980b to 1995b). 
If the CCSS non-contributory programmes played a compensatory role during the crisis, the same cannot be said of state subsidies to other pensions. In 1992, only 1.6 per cent of GDP was spent on CCSS-OADS (90 per cent contributory and 10 per cent non-contributory) but an additional 2.1 per cent of GDP went to pensions of civil servants covered by independent funds. In 1990, the CCSS covered 80 per cent of the total pensioners but only spent 43 per cent of total pension expenditures; conversely, the civil servant funds (which generally covered people with a higher income than those covered by the CCSS) had only 20 per cent of the total number of pensioners but disbursed 57 per cent of total pension expenditure. About 90 per cent of the latter was financed by the government (at a cost of 10 per cent of the fiscal budget); conversely, the state was delinquent in paying a good part of its obligations to finance CCSS pensions. It is obvious, therefore, that state subsidies on pensions were regressive (Mesa-Lago, 1988, 1994a, 1994b; IDB, 1994b).

CCSS administrative expenses as a percentage of total expenditures declined from 8.4 per cent to 3.9 per cent in 1975-94, ranking Costa Rica among the two countries with the lowest administrative costs in the region (see Table 7.13). And yet in 1980 there were 13 employees per 1,000 insured (including all programmes), one of the highest ratios in Latin America. The crisis forced a freezing of personnel, hence the ratio sharply declined in the early 1980s, and stabilized at 8.2 in 1992-4 (still high by international standards). The 1988 ratio in MINSA was 3.4 and, although CCSS requires more personnel due to the type of medical-hospital services (as well as pension administration) it provides, still the gap between the two institutions was quite wide (based on Jaramillo, 1993). The distribution of personnel (both within CCSS and MINSA) is inadequate and there are serious deficiencies at the primary care level. CCSS employees are unionized and exert strong pressure to increase their salaries and fringe benefits (including an exemption from paying contributions to CCSS). In 1987 the average salary of CCSS employees was the highest in the nation and twice the average salary of the insured. At the end of the 1980s, CCSS trade unions won a reduction of 5 hours in the weekly work schedule, which was rapidly filled with extra-hour labour at a cost of US $\$ 1.3$ million (IDB, 1994b; Mesa-Lago, 1994b).

There are some serious deficiencies in the administration of CCSS, including flaws in registration, high evasion and payment delays (estimated from 14 per cent to 38 per cent in 1992), long delays in awarding pensions, poor management of investment funds (resulting in negative or low real yields), and inadequate control to avoid granting welfare benefits to non-insured who are not poor. But not all the blame goes to the CCSS administrators, as the government has often not fulfilled its financial obligations, has put pressure on the CCSS to hire unneeded workers, and has used pension reserves to finance fiscal expenditures (pushing CCSS to invest in non-tradable public securities with negative yields). The crisis and high inflation aggravated some of these problems.

d. Anti-poverty programmes. The principal anti-poverty programme is Fondo de Desarrollo Social y Asignaciones Familiares (FODESAF), established in 1974 and 
expanded in 1983-90 to help alleviate poverty and social deterioration. Although FODESAF funding was initially modest, it eventually increased more than fourfold in 1991-5, reaching 2.4 per cent of GDP. This institution is financed by a payroll tax of 5 per cent paid by employers, plus one-third of the sales tax.

FODESAF has been criticized because of inadequate targeting of the poor. Its budget in 1990 was US $\$ 123$ million, and it reportedly covered 32 per cent of the total population, the highest proportion in the region after Mexico. However, many beneficiaries received two or more benefits (hence inflating the statistics on the percentage of the population covered) and a substantial proportion of the resources did not go to the rural poor but to urban middle and high-income groups. For instance, in 1982-90, the expenditure share of projects for the poorest declined, while the share of projects geared to urban middle-income groups (e.g., housing and credit and training to microenterprises) increased (ILO, 1992b). The FODESAF budget in 1994 increased to $\$ 202$ million. Of this, 33 per cent went for housing; 20 per cent for non-contributory (welfare) pensions; 8 per cent for school meals; 7 per cent for nutrition; 3 per cent for each food coupons, rural aqueducts and land grants; 2.5 per cent for job creation; 1.7 per cent each for basic education, emergency communal homes, and relocation of children; and 15 per cent for other subsidies and basic services to women, old people, minors, rural areas and communities (FODESAF 1993). As we saw in Table 7.10, in 1993, most of these programmes benefited the poorest two quintiles, but still from 6 per cent (food stamps) to as much as 30 per cent (credit and training, housing) went to the richest two quintiles. Furthermore, the wealthiest groups in urban areas received proportionally more than similar groups in rural areas. In 1992, 44 per cent of the households who collected non-contributory pensions were indigent and 15 per cent were poor, but 41 per cent went to the non-poor - mostly to salaried workers with relatively low income or the unemployed. In 1995 the FODESAF budget was increased by 170 per cent to US $\$ 545$ million (with aid provided from IDB plus state funds) and the programme was expected to have a more integrated and targeted approach to the poor (DESAF, 1995).

Another anti-poverty programme is that of the Institute Mixto de Ayuda Social (IMAS), which in 1994 had a modest budget of US $\$ 20$ million. Part of these funds were transferred to 400 social welfare institutions, many of them private or nongovernmental organizations, which helped 31,000 people in need; in addition, a food programme targeted 50,000 females in extreme poverty, many of them living in households with a female head (IDB, 1994b).

Although not targeted to the poorest, the minimum wage policy of the Costa Rican government has at least prevented a number of low-income families from becoming destitute. The real minimum wage performed better than the real mean wage, both during and after the crisis: taking 1980 as the base year, the index of the mean wage declined to a trough of 71 in 1982 , while the minimum wage only decreased to 86 ; by 1994 , the mean wage index had risen to 98 , while the minimum jumped to 113 .

The extensive network of social institutions in Costa Rica compensated for a good many of the costs of the crisis and structural adjustment, while the recovery 
helped to reduce poverty incidence. And yet we have shown already that some antipoverty programmes were not targeted to the poorest (particularly in rural areas), but helped middle and high-income groups (particularly in urban areas) somewhat. Those problems can be partly explained by inefficiencies summarized below.

First, FODESAF alone had 38 programmes in 1994 and, in addition, there were many other government agencies involved in anti-poverty or welfare activities (IMAS, CCSS, MINSA, MEP, National Foundation for Children, etc.). In some cases, the existing infrastructure was not utilized but a new one was created: for example, the National Training Institute was not used by FODESAF for training and development of microenterprises. These programmes were not integrated within a wellthought-out social policy plan, and there was a lack of co-ordination among them; therefore, considerable duplication and overlapping occurred. Second, FODESAF is a state agency (technically a Public Action Programme: PAP) created in 1974 - well before the more successful experience of autonomous Social Emergency Funds (SEF) in the second half of the 1980s, and of Social Investment Funds (SIF) in the early 1990s. As a typical PAP, FODESAF is highly centralized and, although it transfers funds to other institutions, these are virtually all public, hence, very few NGOs, local communities and private businesses receive and administer those funds (IMAS apparently has a better record on the latter). Third, FODESAF is financed through payroll and sales taxes, and this type of financing may have an adverse effect on job creation, due to the heavy burden of social security contributions on enterprises. The recent injection of significant external funds has enlarged the pool of resources, but created problems of sustainability in the long run. Fourth, only 60 per cent of FODESAF funds were actually spent on welfare programmes in 1991 (compared with 92 per cent in 1981); the remaining 40 per cent was indirectly used to finance the fiscal deficits of some public programmes (no information is available on the actual proportion spent in 1992-4). Fifth, until recently there was scant information about the size, location, characteristics and must urgent needs of the poor and indigent through household surveys, thus FODESAF diagnosis and targeting were weak at least up to the 1980s, and the agency lacked well-defined criteria to evaluate the results and impact of its programmes. As a result, part of the anti-poverty resources were not received by the poor, water did not reach the most isolated poor areas, and housing mainly benefited the non-poor. Sixth, the value of some benefits provided by FODESAF was grossly insufficient to cover basic needs - for instance, the non-contributory pension was 10 per cent to 12 per cent of the minimum wage, 65 per cent below the basic minimum needed (ILO, 1992b; IDB, 1994b; UNCTAD, 1994).

\section{The impact of the $1980-85$ crisis and the $1986-95$ recovery on social development}

Table 7.14 summarizes the six most relevant indicators of the crisis and the recovery in Costa Rica and the other nine countries (the most developed in the region) selected for comparison in this study: GDP per capita growth (absolute and per capita), inflation, real minimum wage, urban open unemployment, national 


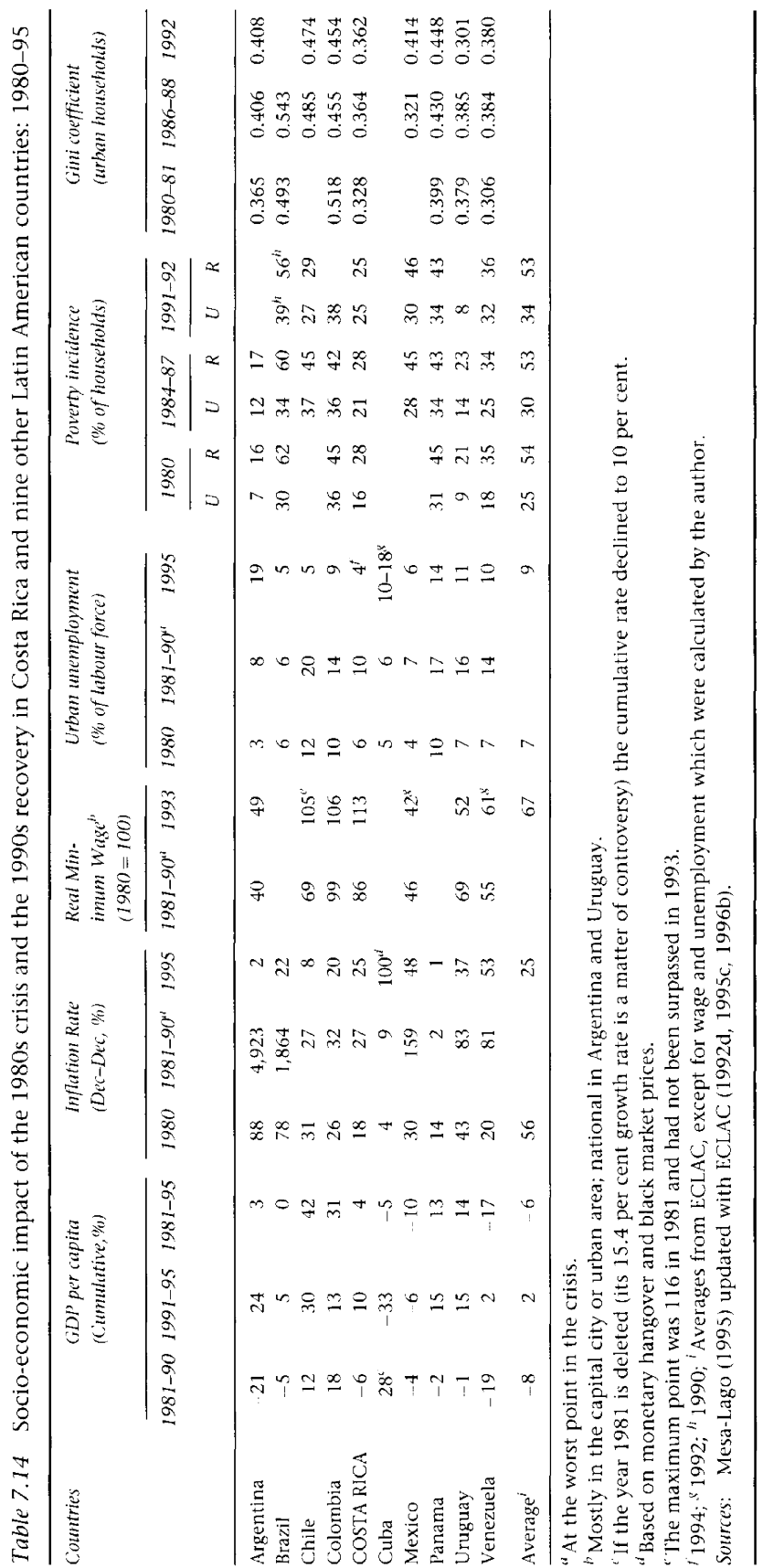


poverty incidence, and inequality (Gini coefficient). The data selected illustrate the situation prior to the crisis, at the worse point in the crisis, and in the recovery or latest year available.

Costa Rica suffered a decline in cumulative GDP per capita ( 6 per cent) over the period 1981-90; only Argentina and Venezuela suffered a worse decrease. By the time the recovery was well established, in 1991-5, Costa Rica's GDP per capita increased 10 per cent, five times the Latin American average. The net outcome of the entire 1980-95 period was modest positive growth of 4 per cent. In 1980, Costa Rica's inflation rate (18 per cent) was among the lowest of the ten countries, and was considerably lower than the regional average ( 56 per cent); in the worst point during the crisis, Costa Rica's inflation reached 27 per cent, and in 1995 it was 25 per cent, equal to the regional average.

Costa Rica's response to the crisis was much more gradualist than was that of many other countries in the region. Chile and Argentina, for instance, adopted a 'shock therapy' that was meant to restructure the economy rapidly with little attention paid to adverse social effects (as well as some adverse economic effects). In Chile, unemployment increased tremendously, real wages declined sharply, income distribution became more unequal and poverty worsened. Costa Rica, on the other hand, took a much more moderate approach to structural adjustment, trying to protect the population from such negative effects - for instance by maintaining the social safety nets it had in place before the adjustment, and adding some new ones.

Costa Rica's performance in terms of social indicators was considerably better than in terms of economic indicators. The real minimum wage in Costa Rica suffered a relatively modest decline of 14 per cent at the worst point in the crisis, and in 1993 had gained 13 per cent over 1980, 46 percentage points above the regional average. Costa Rica's urban open unemployment rate in 1980 (6 per cent) was among the lowest of the ten countries; at the worst point in the crisis the rate peaked at 10 per cent, but by 1995 Costa Rica's urban unemployment rate of 4 per cent was the lowest of the ten countries, and was 3 per cent below the regional average and 2 per cent below its own pre-crisis rate. In 1980, poverty incidence (urban and rural) in Costa Rica ( 16 per cent and 28 per cent) was about one half the regional averages; in 1984-7 urban poverty incidence increased to 21 per cent while rural poverty remained the same, and urban poverty increased further to 25 per cent in 1991, while rural poverty declined slightly, also to 25 per cent. Both urban and rural poverty were still considerably below the regional averages (34 per cent and 53 per cent). In 1980-81 Costa Rica's Gini coefficient (inequality in income distribution: 0.328 ) was the second lowest among the countries in Table 7.14, it increased in 1986-8 but remained in second place; and by 1992 it had declined slightly to 0.362 , although it remained higher than it had been in 1980-81.

As discussed above, the thirteen social indicators compared in Table 7.1 give an even stronger indication of Costa Rica's success in social development: the combined index of these social indicators, as well as the UNDP Human Development Index, ranked Costa Rica in the first place among the ten most developed 
countries in Latin America. But Costa Rica ranked only eighth in terms of GDP per capita in US dollars.

In summary, Costa Rica's performance in macroeconomic indicators (GDP per capita growth in US dollars, inflation) was fair, better than the regional average (ranking between fifth and eighth). Conversely, Costa Rica was among the two or three countries that suffered the least social costs during the crisis, and emerged during the recovery as the best in social development. The social institutions, policies and exogenous factors discussed in this study undoubtedly played a key role in Costa Rica's remarkable social performance. The gradualist approach of structural adjustment and the very short period of the transition were additional factors that helped to ameliorate both the economic decline and social costs.

But this positive picture would not be complete unless we go beyond macro indicators and compare the current situation with that prior to the crisis. It is not clear that national poverty incidence was lower in 1992 than in 1980, and most sources estimate that poverty and indigency still are highly concentrated in rural areas, and that income distribution worsened (Tables 7.8 and 7.9). The incidence of at least three out of nine major contagious diseases in the early 1990 s was higher than in 1980 and even 1961. The ratios of beds per 1,000 inhabitants declined, the ratio of physicians per 10,000 decreased, and immunization rates also fell, leading to serious epidemics in 1990-93. Some of those changes were a result of increased efficiency, but others were due to insufficient resources and suggest a decline in quality. In 1993, CCSS coverage of the OADS-contributory programme and the real value of pensions were lower than in 1980, and the welfare pension was grossly insufficient to cover basic needs.

Resources allocated to social programmes also declined in most cases, or were not adequately distributed according to need. As discussed above, the social share of total public expenditures in 1993 was below that of 1982: the educational and non-CCSS health shares were smaller, but the CCSS share was bigger. Over this period curative health care gained resources at the expense of preventive care, and tertiary education gained at the expense of lower levels. In 1982-90, budgets of anti-poverty programmes most beneficial to the poorest (nutrition, health, welfare pensions) were cut by 12 per cent to 35 per cent, while programmes geared to middle-income groups (housing) were increased by 32 per cent. In 1994 one-third of all resources to fight poverty were allocated to the housing programme, which had the least progressive impact.

\section{Is social development sustainable in Costa Rica? Recommendations for the future}

This chapter has discussed the combination of factors that contributed to Costa Rica's superior social performance. Favourable geographic features, the relatively early development of the wage labour sector and entry into world markets, combined with political stability and low defence expenditures, established an economic and social environment that was conducive to social development. When the state took on a strong development role it was able to take advantage of these 
favourable conditions to achieve substantial progress in social conditions. Early compulsory education led to high educational indicators and equal access of females to education. Emphasis on health care, combined with a financial system that promoted universal health care coverage, as well as strong nutrition interventions, resulted in very good health indicators. The commitment to equity led to a rising minimum wage, and one of the most equal income distributions in the region. The gradualist approach taken to structural adjustment, and the rapid recovery of social spending, helped maintain this progress.

However, some problems remain. All data accumulated in this study (on poverty, income distribution, health care, education, social security) consistently show that there are relatively small groups either excluded from or receiving very low quality social services: the rural population (particularly outside the central region), the non-educated, the elderly, women heads of household, agricultural workers (and small farmers), and those in the urban informal sector (street vendors, domestic servants). Costa Rica has one of the highest social shares of both GDP and the public budget in the region, and its public social network is impressive, but it has too many agencies and programmes in need of integration, decentralization, improvement in efficiency, participation from below and, above all, better targeting of the small pockets of disadvantaged groups. The vigorous expansion of public social services has left little space for a private sector role, except in higher education; and collaboration between the public and private sectors is limited.

Two crucial questions are addressed in this final section: are the social achievements sustainable in the long run and, if so, how; and what social policy changes are needed to cope with the disadvantaged groups that remain.

Costa Rica should be able to maintain its most important social programmes without further increasing their burden on GDP, the fiscal budget, and the payroll. In 1992 Costa Rica's social expenditures were 15.6 per cent of GDP, much higher than those of the United States and Japan. Costa Rica's social share of central government expenditures was 67.3 per cent in 1992, similar to that of France and more than double that of the United States (World Bank, 1995a; ILO, 1996). Even without military expenditures, a developing country with relatively low GDP per capita cannot afford an increase in such burdens, but as Costa Rica's population ages its pension programme will require increasing resources. The only way out of this dilemma is to reallocate social resources (prioritizing the most important programmes and targeting disadvantaged groups) and improve their efficiency, along the lines recommended below.

Social security (CCSS) expenditures take about half of the social share of both GDP and the fiscal budget, while education, other health care programmes, and anti-poverty expenditures combined take the other half. In spite of the high legal payroll contribution and other legal state obligations, the financial and actuarial equilibrium of the CCSS has deteriorated. Some positive measures taken in the 1990s, including better investment practices and tightening of entitlement conditions, have improved the financial equilibrium in the medium term, but they will not be able to correct the actuarial deficit, and increases in contributions are 
not advisable. The CCSS, therefore, must become more efficient by reducing its personnel and generous fringe benefits; further increasing retirement ages (to 65 years for both sexes); pursuing a more productive investment of its reserves; and incorporating and standardizing the independent pensions funds of the Legislative and Judicial branches. An overall reform of pensions is under study in 1996 to increase the retirement age and create a mandatory supplementary programme in which public and private institutions would compete for the insured (Mesa-Lago, 1994b; Durán, 1996).

The health care sector also suffers from overlap, waste and inefficiency due to the separation of CCSS and MINSA facilities and services. Full integration of both institutions is necessary, as is a reallocation of resources in favour of prevention, primary health care and targeting of the groups in most need, particularly the isolated rural and marginalized urban populations. Hospitals with low occupancy rates should be shut down, and even more emphasis should be placed on rural health posts, health centres and clinics. The health care infrastructure currently managed by MINSA should be given priority for rehabilitation of the physical plant and equipment and maintenance. Consideration should be given to introduction of moderate user fees (exempting those in need) in order to control unnecessary use of services and over prescription of medicine, as well as to increase the revenue of hospitals. Decentralization of integrated services and higher community participation are essential. Collaboration with the private sector should be expanded, based on those programmes that have proven to be effective in reducing costs and raising users' satisfaction. Privatization of non-medical services such as food catering, cleaning and so forth should be explored. The gap between paramedic personnel and physicians needs to be closed, and the latter should be compelled to fulfil their duties through a combination of sanctions and incentives such as capitation and similar techniques (Mesa-Lago, 1992).

Education has proven to be a determinant factor in access to and quality of health care, social security coverage, employment, income and poverty reduction. Resources from other public social programmes (such as housing and pensions for high-income insured, particularly civil servants) should be transferred to education and, within it, from higher to primary and secondary levels. Targeting of resources is essential, and priority should be given to addressing adult illiteracy and improving rural primary schools and vocational technical schools to enable them to develop skills that meet market demand. New mass education techniques such as TV and video should be expanded. The MEP should be reorganized and strengthened, teachers' promotions should be based on merit instead of seniority; supervision and evaluation of teaching must be increased; teachers should be adequately paid and those who are redundant or do not fulfil their duties dismissed. More resources must go to educational materials and maintenance of the infrastructure. Groups with educational deficiencies must be identified and given priority. The Constitution should be amended to eliminate (or at least reduce) the budget proportion mandated to universities and, within them, fiscal resources should be transferred from humanities and social sciences to scientific and technical departments (particularly agricultural sciences and business). Free tuition 
should be granted only to those in need and the rest of the students should pay proper tuition. Most of the new resources should go to fellowships (including tuition and maintenance) for capable but poor students. Entrance examinations to universities should be tightened to increase quality and improve the studentteacher ratio. Redundant staff should be dismissed and a system of incentives introduced to motivate professors; allocation for research must be increased, as should practical internships and interrelations with foundations, business and the private sector (Sanguinetty, 1988b; IDB, 1994b).

Anti-poverty programmes should be integrated or highly co-ordinated, while their administration should be decentralized to allow better targeting of the most disadvantaged groups. Priority should be given to programmes that have the greatest impact in helping the poor - nutrition, primary health care, welfare pensions and skills-training - while housing programmes should be drastically cut and focused on the rural and urban poor. FODESAF should continue transferring funds rather than administering them directly, but not almost exclusively to public agencies. Participation of NGOs, local communities and non-profit private institutions should be promoted. Allocation of resources should be based on a clear set of criteria including targeting of the poor, efficiency and sustainability.

It is obvious that the recommended changes will meet with political difficulties, resistance from the entrenched bureaucracy, and pressure from interest groups adversely affected. But without these reforms, Costa Rica's remarkable social achievements will be in jeopardy, and the foundations of its democracy eroded. A nation that has shown a unique historical commitment to universalization and equity in the social arena should now tackle the transformations needed to sustain its progress, reaffirm its democracy and forge an even better society.

\section{Notes}

1 A dispossessed or 'indigent' is defined either as one who cannot satisfy the basic food, clothing, housing and health-care needs or who earns less than 75 per cent of the minimum agricultural wage; a means test is done twice a year by the CCSS, but the record does not show whether the entitled person is insured or a dispossessed, legally ensuring equal health care treatment for both type of users.

2 Table 7.8 puts together all the estimates available for poverty and indigency rates among households: national, urban and rural (there are also two series on poverty incidence among individuals, for 1971-86, not shown in the table: Sauma and Trejos (1990) and PREALC (1992)). The longest and most consistent series (that also estimates indigency) is that of ECLAC (1970-92) followed by those of Sauma-Trejos and Trejos (1971-86 and 1986-93). We will focus on these two series because they are the longest and are fairly similar (they show lower poverty incidence than the PREALC series).

3 Other available series are either incomplete or underestimate social expenditures. For instance, the ILO (1996) significantly underestimates social security expenditures; conversely ECLAC (1995b) overestimates health expenditures; the IMF (1980a to 1994a) provides a comprehensive series fairiy similar to the author's, but with figures lower in 1972-7 and higher figures in 1978-93. Part of the expenditures of anti-poverty programmes are not included in Table 7.11, because it was impossible to separate those not transferred to health care, social security and education, but the total spent by antipoverty programmes reached 2.4 per cent of GDP in 1994. 


\section{References}

Acuña Ulate, José A. (1993) 'Un enfoque económico de los problemas de financiamiento de los servicios de salud,' Revista de Ciencias Administrativas de la Seguridad Social, 1(2):21-8.

Acuña Ulate, José A. and Fabio A. Durán V. (1994) Extensión de la cobertura del seguro de vejez, invalidez y muerte: Diagnóstico y estrategias. San José: CCSS.

AID (1992) Costa Rica: The Effects of Structural Adjustment Measures. Washington, DC: Agency for International Development, Bureau for Latin America and the Caribbean.

Aguilar, Pilar (1990) 'The evolution of the Costa Rican education profile', in Colin Brock and Donald Clarkson (eds), Education in Central America and the Caribbean. New York: Routledge.

Altimir, Oscar (1984) 'Poverty, income distribution and child welfare in Latin America: a comparison of pre- and post-recession data', World Development 12(3):261-82.

Altimir, Oscar (1993) 'Income Distribution and Poverty through Crisis and Adjustment', Working Paper No. 15. Santiago: ECLAC.

Andic, Fuat (1994) 'Ingresos familiares en Costa Rica: 1988', Working paper. San José: Universidad de Costa Rica.

Baldares, Manuel de Jesús (1985) La distribución del ingreso y los sueldos en Costa Rica. San José: Editorial Costa Rica.

Baldares, Manuel de Jesús (1988) Working Paper. University of Pittsburgh.

BCCR (1986) Estadísticas 1950-1985. San José: Banco Central de Costa Rica.

BCCR (1988) Datos socio-económicos de Costa Rica. San José: Banco Central de Costa Rica.

BCCR (1989a) Cuentas nacionales de Costa Rica 1978-1987. San José: Banco Central de Costa Rica.

BCCR (1989b to 1992b) Amuario Estadístico, Cuentas Nacionales 1984-1988 to 1987-1991. San José: Banco Central de Costa Rica.

CCSS (1976 to 1991a) Memoria Anual 1975 to 1990. San José: Caja Costarricense de Seguro Social.

CCSS (1990b to 1995b) Anuario Estadístico 1989 to 1994. San José: Caja Costarricense de Seguro Social.

CCSS (1995c) Costa Rica: Indicadores de seguridad social 1990-1994. San José: Caja Costarricense de Seguro Social, Dirección Actuarial y de Planificación Económica.

Cartín Carranza, Ronald A. (1991) Sistema de pensiones en América Latina: Diagnóstico y alternativas de reforma. Costa Rica. Santiago: ECLAC.

Castro Valverde, Carlos and Mauricio González ()viedo (eds) (1992) Costa Rica: balance de la situcción. San José: Centro de Estudios para la Acción Social.

CELADE (January 1977, January 1984, January 1991, July 1991) Boletín Demogrófico. Santiago: Centro Latinoamericano de Demografía.

Céspedes, Víctor Hugo (1973) 'Costa Rica: La distribución del ingreso y el consumo de algunos alimentos', Serie Economía y Estadística, No. 45. San José: Universidad de Costa Rica.

Céspedes, Víctor H. and R. Jiménez (1988) Evolución de la pobreza en Costa Rica. Estudios 5. San José: Academia de Centroamérica.

Céspedes, Víctor H. et al. (1990) Costa Rica frente a la crisis: Políticas y resultados. San José: Academia de Centroamérica.

DESAF (1995) Reestructuración del FODESAF. San José: Dirección de Desarrollo Social y Asignaciones Familiares.

Durán, V. Fabio (1993) 'Seguridad social y privatización de servicios de salud', Revista de (iencias Administrativas de la Seguridad Social, 1(2):13-19.

Durán, V. Fabio and Róger González Ch. (1994) 'El gasto público en salud durante el período 1980-1993', Revista de Ciencias Administrativas de la Seguridad Social, 2(2):15-23.

ECIAC (1965a to 1995a) Economic Survey of Latin America [and the Caribbean] 1984 to 1993. Santiago: Economic Commission for Latin America and the Caribbean.

ECLAC (1977b to 1996b) Statistical Yearbook for Latin America land the Caribbeanl 1976 to 1995. Santiago: Economic Commission for Latin America and the Caribbean. 
ECLAC (1985c to 1995c) Preliminary Overview of the Economy of Latin America [and the Caribbean] 1985 to 1995. Santiago: Economic Commission for Latin America [and the Caribbean.

ECLAC and the Caribbean (1992d) El perfil de la pobreza en América Latina a comienzo de los años noventa. Contribution by ECLAC to the third regional conference on poverty in Latin America, held in Santiago, November.

ECLAC (1993e) Antecedentes estadisticos de la distribución del ingreso en los ochenta,Costa Rica. Santiago: Economic Commission for Latin America and the Caribbean.

ECLAC (1995f) Seguridad social y equidad en el Istmo Centroamericano. Mexico City: Economic Commission for Latin America and the Caribbean.

ECLAC (1994g, 1995g) Social Panorama of Latin America 1994, 1995. Santiago: Economic Commission for Latin America and the Caribbean.

FOSEDAF (Fondo de Desarrollo Social y Asignaciones Familiares) (1993) Presupuesto ordinario. San José: Ministerio del Trabajo y Seguridad Social.

Ghai, Dharam (ed.) (1991) The IMF and the South: The Social Impact of Crisis and Adjustment. London: Zed Books.

González González, Fernando (1987) Educación costarricense: Desarrollo histórico del procesopedagógico costarricense. San José: Editorial Universidad Estatal a Distancia.

Güendel G., Ludwig and Juan D. Trejos (1994) Reformas recientes en el sector salud de Costa Rica, Reformas de Política Pública, No. 18. Santiago: CEPAL.

IDB (1994b) A la búsqueda del siglo XXI: Nuevos caminos de desarrollo en Costa Rica. San José: Inter-American Development Bank.

IDB (Inter-American Development Bank) (1969a to 1995a) Economic and Social Progress in Latin America 1968 to 1995. Washington, DC: Johns Hopkins University Press.

IDB-UNDP (Inter-American Development Bank and United Nations Development Programme) (1993) Social Reform and Poverty. Washington, DC and New York.

ILO (1976 to 1994) Year Book of Labour Statistics 1975 to 1994. Geneva: International Labour Office.

ILO (1992b) Estabilización, ajuste estructural y políticas sociales en Costa Rica: El papel de los programmeas compensatorios, Interdepartmental Project on Structural Adjustment, Occasional Paper, No. 1. Geneva: International Labour Office.

ILO (1996) The Cost of Social Security 1987-89. Geneva: International Labour Office.

IMF (1980a to 1994a) Government Finance Statistics Yearbook 1980 to 1994. Washington, DC: International Monetary Fund.

IMF (1996) International Financial Statistics Yearbook 1990 to 1995. Washington, DC: International Monetary Fund.

Jaramillo Antillón, Juan (1993) Salud y seguridad social. San José: Editorial Universitaria de Costa Rica.

Mesa-Lago, Carmelo (1988) 'Análisis económico de los sistemas de pensiones en Costa Rica y recomendaciones para su reforma.' Washington DC: Development Technologies, SA.

Mesa-Lago, Carmelo (1989) Ascent to Bankruptcy: Financing Social Security in Latin America. Pittsburgh: University of Pittsburgh Press.

Mesa-Lago, Carmelo (1990) La seguridad social y el sector informal. Santiago: PREALC.

Mesa-Lago, Carmelo (1992) Health Care for the Poor in Latin America and the Caribbean. Washington DC: Pan American Health Organization and InterAmerican Foundation.

Mesa-Lago, Carmelo (1994a) Changing Social Security in Latin America: Toward Alleviating the Social Costs of Economic Reform. Boulder: Lynne Reinner.

Mesa-Lago, Carmelo (1994b) 'Estudio sobre la situación de la seguridad social en la región de México, Centroamérica y el Caribe: Avances, problemas y recomendaciones.' Miami: Informe para el IDB, December.

Mesa-Lago, Carmelo (1996a) 'The reform of social security pensions in Latin America: public, private, mixed and parallel systems.' University of Pittsburgh.

Mesa-Lago, Carmelo (1996b) 'Costa Rica', in Alternative Models of Economic Development in Latin America: Socialist, Market and Mixed Approaches. University of Pittsburgh. 
Mesa-Lago, Carmelo (1997) 'Social welfare reform in the context of economic-political liberalization: Latin American cases', World Development, 25(4):497-517.

MEP (1992) Expansión del sistema educativo costarricense, 1992. San José: Ministerio de Educación Pública.

MEP (1993) Costos, gastos e indicadores de la educación pública en Costa Rica. San José: Ministerio de Educación Pública.

MIDEPLAN (1992) El proyecto de reforma del sector salud: Resumen. San José: Ministerio de Planificación Nacional.

MIDEPLAN (1994a) Perfil de la pobreza en Costa Rica. San José: Ministerio de Planificación Nacional.

MIDEPLAN (1994b) Costa Rica: Programmeas y proyectos estatales para la superación de la pobreza. San José: Ministerio de Planificación Nacional.

MIDEPLAN (1995) Costa Rica, Indicadores básicos 1995. San José: Ministerio de Planificación Nacional.

Mora, Minor and José M. Valverde (1993) Privatización, deterioro e improvisación en el sector salud. San José: Espacios Consultores Asociados.

Morley, Samuel A. and Carole Alvarez (1992) Recession and the Growth of Poverty in Costa Rica. Washington, DC: IDB.

OFIPLAN (1982) Evolución socioeconómica de Costa Rica 1950-1980. San José: Oficina de Planificación Nacional y Política Económica.

PAHO $(1964,1986,1990,1994)$ Health Conditions in the Americas 1961-1964, 1986, 1990, 1994. Washington, DC: Pan American Health Organization.

PAHO (1992) Health Statistics from the Americas. Washington, DC: Pan American Health Organization.

PREALC (1992) Costa Rica: Politicas para pagar el gasto social. Santiago, no. 366.

Presidencia de la República (1995) Costa Rica ante el reto del desarrollo social. San José: Cumbre Mundial de Desarrollo Social.

Quirós Coronado, Roberto (1991) Costa Rica: La atención médica en la seguridad social. Ottawa: paper for 5 th regional conference of AISS.

Riboud, Michelle (1990) Costa Rica: El gasto puiblico en los sectores sociales. Washington, DC: World Bank.

Rocío Pascua, María del and Luis A. Valverde (1987) Bienestar social en Costa Rica: Una reseña de su desarrollo. San José: Universidad de Costa Rica, Instituto de Investigaciones Sociales.

Saenz, Rocío (1994) 'la Reforma de la salud en Costa Rica', unpublished paper, University of Pittsburgh.

Sanguinetty, Jorge A. (1988a) La salud y el seguro social en Costa Rica. San José: Development Technologies, Inc.

Sanguinetty, Jorge A. (1988b) La educación general en Costa Rica: La crisis y sus posibles soluciones. San José: Development T'echnologies, Inc.

Sauma, Pablo and Juan 1). Trejos (1990) Evolución reciente de la distribución del ingreso en Costa Rica: 1976-1986. San José: Universidad de Costa Rica, Instituto de Investigaciones en Ciencias Económicas.

Sojo, Ana (1989) 'Social Policies in Costa Rica', CEPAL Review, 38(August): 105-19.

Sojo, Ana (1994) Politica social en Costa Rica: Reformas recientes. San José: Facultad Latinoamericana de Ciencias Sociales.

Trejos S., Juan Diego (1990) Pobreza y politica social en Costa Rica. San José: MIDEPI.AN.

Trejos S., Juan Diego (1994) 'Evolución reciente de la pobreza en Costa Rica', San José: Informe para el $\mathrm{IDB}$.

Trejos S., Juan Diego and M. L. Elizalde (1985) 'Costa Rica: La distribución del ingreso y el acceso a los programmeas de carácter social', Documento de Trabajo No. 90. San José: Universidad de Costa Rica.

Trejos S., Juan Diego and M. L. Flizalde (1992) 'Servicios de salud para indigentes en Costa Rica', y 'Pensiones no contributivas en Costa Rica', in From Platitudes to Practice: Targeting Social Programmes in Latin America. Washington, DC: World Bank, LACTD, Report No. 21. UN (1964 to 1985) Construction Statistical Yearbook. New York: United Nations. 
UNCTAD (United Nations Commission for Trade and Development) (1994) Recent Developments in Social Funds and Safety Nets and Exchange of Experiences on Poverty Reduction Impacts of Social Funds and Safety Nets, including Mobilization of Domestic and External Resources for Poverty Alleviation. Geneva: Standing Committee on Poverty Alleviation.

UNDP (United Nations Development Programme) (1992 to 1995) Human Development Report 1992 to 1995. New York: Oxford University Press.

UNESCO $(1993,1994)$ Statistical Yearbook 1993, 1994. Paris: United Nations Educational, Scientific and Cultural Organization.

UNRISD (1995a) Adjustment, Globalization and Social Development. Geneva, United Nations Research Institute for Social Development.

UNRISD (1995b) After the Social Summit: Implementing the Programme of Action. Geneva: United Nations Research Institute for Social Development.

World Bank (1988a to 1995a) World Development Report 1988 to 1995. New York: Oxford University Press.

World Bank (1991b to 1995b) Social Indicators of Development 1990 to 1995. Baltimore: Johns Hopkins University Press.

World Bank (1985c to 1995c) World Tables 1984 to 1994. Washington, DC: World Bank.

WHO (1964 to 1990) World Health Statistics Annual 1964 to 1990. Geneva: World Health Organization. 